\title{
Impact of breastfeeding interventions among United States minority women on breastfeeding outcomes: a systematic review
}

Sofia Segura-Pérez ${ }^{1 *}$ (D, Amber Hromi-Fiedler ${ }^{2}$, Misikir Adnew ${ }^{2}$, Kate Nyhan ${ }^{3}$ and Rafael Pérez-Escamilla²

\begin{abstract}
Background: In the U.S., strong ethnic/racial, socioeconomic, demographic, and geographic breastfeeding (BF) inequities persist, and African American and Hispanic women are less likely to meet their breastfeeding goals compared to White women. This systematic review (SR) was designed to answer the question: What is the impact of breastfeeding interventions targeting ethnic/racial minority women in the U.S. on improving BF initiation, duration and exclusivity rates?
\end{abstract}

Methods: The SR was conducted following the Institute of Medicine Guidelines and the Preferred Reporting Items for Systematic Reviews and Meta-Analyses checklist. The study protocol was developed and registered a priori in PROSPERO (ID\#CRD42020177764). The electronical databases searched was MEDLINE All (Ovid). Search strategies were led by the team's expert public health librarian using both controlled vocabulary and free text queries and were tested against a validated set of relevant papers included in existing reviews. The GRADE methodology was used to assess the quality of the studies.

Results: We included 60 studies that had randomized $(n=25)$, observational $(n=24)$, quasi-experimental $(n=9)$, or cross-sectional $(n=2)$ designs. The studies focused on populations that were multi-ethnic/racial $(n=22)$, only Hispanic $(n=24)$, only Black $(n=13)$, and only American Indian $(n=1)$. The study interventions were classified following the socioecological model: macrosystem/policy level $(n=6)$; community level $(n=51)$, which included healthcare organizations ( $n=34)$, The Special Supplemental Nutrition Program for Women, Infants, and Children (WIC) $(n=9)$, and community organizations/public health institutions $(n=8)$; and interpersonal level $(n=3)$.

Conclusions: Policy and community level interventions delivered through WIC, healthcare facilities, and community agencies) are likely to improve BF outcomes among women of color. The combination of interventions at different levels of the socioecological model has not been studied among minority women in the U.S. Implementation science research is needed to learn how best to scale up and sustain effective BF interventions, taking into account the needs and wants of minority women. Thus, it is strongly recommended to conduct large scale implementation research studies addressesing how to strengthen the different health and social environments surrounding women of color in the U.S. to improving their BF outcomes.

Keywords: Breastfeeding, Ethnic/racial minorities, Policy, Socioecological model

\footnotetext{
* Correspondence: sofias@hispanichealthcouncil.org

'Hispanic Health Council, 175 Main Street, Hartford, CT 06106, USA

Full list of author information is available at the end of the article
}

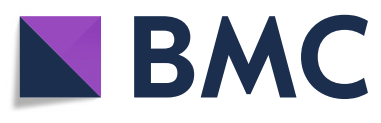

(c) The Author(s). 2021 Open Access This article is licensed under a Creative Commons Attribution 4.0 International License, which permits use, sharing, adaptation, distribution and reproduction in any medium or format, as long as you give appropriate credit to the original author(s) and the source, provide a link to the Creative Commons licence, and indicate if changes were made. The images or other third party material in this article are included in the article's Creative Commons licence, unless indicated otherwise in a credit line to the material. If material is not included in the article's Creative Commons licence and your intended use is not permitted by statutory regulation or exceeds the permitted use, you will need to obtain permission directly from the copyright holder. To view a copy of this licence, visit http://creativecommons.org/licenses/by/4.0/ The Creative Commons Public Domain Dedication waiver (http://creativecommons.org/publicdomain/zero/1.0/) applies to the data made available in this article, unless otherwise stated in a credit line to the data. 
This article is a part of the Interventions and policy approaches to promote equity in breastfeeding collection, guest-edited by Rafael Pérez-Escamilla, PhD and Mireya Vilar-Compte, PhD

\section{Background}

A constellation of short and long-term health benefits of breastfeeding $(\mathrm{BF})$ for mothers and children have been well documented [1-3]. Breastfed compared to non-breastfed infants have lower rates of infectious diseases, childhood obesity, and improved cognitive outcomes [4-6]. Additionally, BF protects mothers against breast and ovarian cancers, type 2 diabetes, and cardiovascular disease $[3,7]$. These benefits increase with BF exclusivity during the first 6 months of life and longer duration of any BF $[3,4,7]$.

In the United States of America (U.S.), the Healthy People Initiative (HP) establishes evidence-based goals with the purpose of monitoring and improving the health of all Americans [8]. Increasing the proportion of breastfed infants is one of the Healthy People 2020 (HP2020) goals to improve maternal, infant, and child health nationally [8]. Five specific BF indicators and corresponding targets are used to monitor the progress made towards reaching this HP2020 goal: BF initiation (81.9\%), any BF at 6 months (60.6\%), exclusive BF (EBF) at 3 months (46.2\%), EBF at 6 months (25.5\%), and continued BF at 12 months (34.1\%) [9]. The Centers for Disease Control (CDC) Breastfeeding Report Card, produced every two years, reports on these indicators using data from the annual National Immunization Survey (NIS). Findings from the 2020 Report Card, which used National Immunization Survey (NIS) data from infants born in 2017 [10], showed improvements in all HP2020 BF targets (compared to the 2018 Report Card) and almost all targets were reached or surpassed [11]. Indeed, most mothers initiated BF (84.1\%), more than half of mothers breastfed for 6 months (58.3\%), 35.3\% of mothers breastfed through 12 months, almost half of mothers did EBF for 3 months (46.9\%), and one quarter of mothers did EBF for 6 months (25.6\%). When BF rates from the 2020 report card were compared with those from the 2011 report card, the time at which the HP 2020 goals were first assessed, it was found that BF initiation, duration, and exclusivity rates in the U.S. had improved significantly over the last 10 years [12]. However, the 2017 NIS data showed that BF inequities continue to exist. Non-Hispanic Black infants continued to have the lowest prevalence for having ever been breastfed (73.7\%) compared with non-Hispanic White infants $(86.7 \%)$ as well as all the other racial groups (Hispanic 84.1\%, Asian 90\%, Hawaiian/Pacific Islander 85.2\%, American Indian (AI)/Alaska Native (AN) 80.7\%) [13]. Non-Hispanic Black infants also had lower BF duration and exclusivity rates for all HP2020 BF indicators when compared with non-Hispanic Whites, indicating that this racial inequity in BF persists [14-16]. Among Hispanics, while they had similar BF initiation rates as non-Hispanic Whites, they had significantly lower rates for BF duration and exclusivity. Only non-Hispanic White and Asian women achieved all the targeted indicators set by HP2020. Although BF duration and exclusivity data could not be calculated for Hawaiian/Pacific Islander and AI/AN using the 2017 NIS data [13], an article presenting earlier NIS data from 2013 showed that AI/AN and Hawaiian/Pacific Islander women were below the HP2020 BF targets, and had significantly lower BF initiation, exclusivity, and duration rates than their White counterparts [17].

In the U.S., strong and persistent socioeconomic, demographic, and geographic BF inequities also persist. The 2017 NIS data demonstrated lower BF initiation rates among women with less than a high school education (73.6\%), younger than 20 years old (74\%), with incomes below the poverty level (76.6\%), who were single mothers (75.1\%), and living in non-metropolitan areas (77.5\%) [13]. These findings are important for understanding BF inequities among minority women who, in large part due to social inequities, are strongly affected by poverty, low levels of education, vulnerable family structures, and geographical segregation. Disadvantages with regards to these social determinants of health pose many BF challenges, including lack of access to quality BF education, social and lactation management support, maternity protection benefits, and culturally appropriate health care services [18-21].

Among BF women, the early introduction of formula has been linked with shorter BF duration and exclusivity $[22,23]$. For this reason, it is concerning that the 2020 BF Report Card shows that $19.2 \%$ of infants that were ever breastfed received formula before 2 days of age, which increased from rates reported in the $2018 \mathrm{BF}$ Report Card (17.2\%). However, a recently published analysis based on NIS data from 2009 to 2015 and broken down by race/ethnicity among BF infants, shows that the prevalence of formula supplementation at $<2$ days in 2015 was higher among Hispanic (23.2\%), Black (20.9\%), and Asian (21.4\%) infants compared with nonHispanic Whites (12.7\%) and the national rate $(17.2 \%)$ [24]. Furthermore, formula supplementation rates at $<2$ weeks postpartum were higher among Hispanics (27.0\%), Blacks (25.3\%), and Asians (25.5\%) compared with Whites (17.5\%) and the national average (21.7\%) [25].

$\mathrm{BF}$ ethnic/racial inequities are a major concern because of the inability for most socio-economically vulnerable women to not be able to BF for as long as is recommended, which can be considered as a violation of their right to make the best decision on how to feed their infants [26, 27]. Furthermore, this inequity leads to 
hundreds of millions of dollars lost in healthcare expenditures and work productivity since the health of women and their children is put at risk as a result of not being able to $\mathrm{BF}$ as recommended [28].

\section{Objectives}

The current BF situation in the U.S. calls for improving investments in protecting, promoting, and supporting BF among minority women. For this reason, it is important to identify effective interventions that have the potential to be scaled up to continue improving BF while at that same time reduce racial/ethnic BF inequities. Thus, the main goals of this systematic review (SR) are to: (a) integrate the literature on interventions conducted in the U.S. among minority pregnant or postpartum women designed to improve BF outcomes (BF initiation, duration, and exclusivity), (b) map them to the socioecological model [29, 30] and (c) assess the interventions' potential for scaling up following the Breastfeeding Gear Model (BFGM) framework (see Table 1) [31].

The primary question that this systematic review answers is: What is the impact of breastfeeding interventions targeting minority women in the U.S. on improving BF initiation, duration, and exclusivity rates among this population? This SR is needed because

\section{Table 1 The Breastfeeding Gear Model}

\begin{tabular}{l} 
The evidence-based Breastfeeding Gear Model (BFGM) posits that the \\
engine needed by countries to successfully scale up and sustain breast- \\
feeding programs at the national level includes 7 peripheral gears and a \\
master coordinating gear [31]. Evidence-informed advocacy is needed \\
to generate the political will that results in legislation leading to pol- \\
icies with earmarked resources for the effective protection, promotion \\
and support of breastfeeding. These resources are essential for building \\
and sustaining the workforce capacity through sound education and \\
training and for the proper implementation of facility (e.g., Baby Friendly \\
Hospitals) and community based (e.g. breastfeeding counseling) pro- \\
grams (training and implementation gear). Social marketing through \\
behavior change communication campaigns that address society at \\
large are needed to educate and elicit support for breastfeeding \\
mothers including family members, friends, health care providers, and \\
decision makers. Implementation research and evaluation is needed \\
to ensure that scaling up bottle neck are identified and addressed on \\
time for long term success and sustainability. The central master or co- \\
ordination gear is typically conformed by a national breastfeeding co- \\
ordinating entity that needs to be well funded and empowered to \\
monitor goals and lead the intersectoral coordination needed to ensure \\
that the complex breastfeeding system work. \\
The BFGM has been operationalized into the Becoming Breastfeeding \\
Friendly initiative (BBF), a policy tool-box for decision makers interested \\
in scaling up their breastfeeding programs at the national level using \\
evidence of strengths and weaknesses in each of the gears of the BFGM. \\
BBF includes metrics and how to set up a policy development process \\
through an intersectoral committee where civil society organization and \\
international agencies are also represented [123, 124]. BBF has now been \\
successfully applied in 8 countries across 5 world regions; Germany, \\
Ghana, England, Mexico, Myanmar, Samoa, Scotland, and Wales (Pérez- \\
Escamilla R. Becoming Breastfeeding Friendly, Yale School of Public \\
Health. www.bbf.yale.edu (accessed October 27,2020 ). \\
\hline
\end{tabular}

previous ones focused on single ethnic/racial groups (i.e. African American women [32], Hispanic [33], and Native Hawaiians and Pacific Islander women [34]) or were conducted over a decade ago [35]. Furthermore, except for one conducted focusing on an AfricanAmerican population [32], none of these reviews mapped findings through the lens of the socioecological model nor did they examine the scaling up potential based on systems thinking approaches.

\section{Methods}

This SR was conducted following the Institute of Medicine Guidelines [36] and the Preferred Reporting Items for Systematic Reviews and Meta-Analyses checklist [37]. The study protocol was developed and registered a priori in PROSPERO (ID\#CRD42020177764).

\section{Literature search strategy}

We searched the database MEDLINE on the Ovid platform. Ovid MEDLINE ALL contains records from 1946 through the most recent daily update. It includes not only MEDLINE records but also epub ahead of print, in-process, and other non-indexed citations. Although in our protocol, we anticipated searching three other databases: CINAHL (Ebsco), Embase (Ovid), Web of Science Core Collection (as licensed at Yale), and PsycINFO (Ovid); we did not do so because of the comprehensiveness of the MEDLINE ALL search in the context of limited resources.

The sensitive search strategy was developed by a medical librarian $(\mathrm{KN})$, tested against validation articles previously identified by the authors, and peer reviewed by an independent medical librarian using the Peer Review Electronic Search Strategies (PRESS) guidelines [38]. The full search strategy is provided in an online supplementary material 1 . It includes controlled vocabulary and keyword searches for the concepts of breastfeeding and minority populations. A validated hedge for health equity papers was considered, but after testing against our validation articles, we preferred an approach that focused on search terms for minority groups and socio-economic status, rather than the longer list of health equity terms articulated by Prady [39].

Articles published before 2009 were not retrieved for screening because of changes in breastfeeding policy recommendations at that time. Articles indexed with the animal label were not retrieved for screening unless they were also indexed with the human label. Articles indexed with a geographic subject heading were not retrieved for screening unless their geographic label was potentially related to the United States; articles with no subject indexing or United States subject indexing were retrieved and screening. This approach increased specificity without reducing sensitivity and allowed us to 
operationalize the minority population concept of the search with many potentially relevant terms.

The MEDLINE records retrieved by the search on April 17, 2020 were uploaded to Covidence, which identified all duplicate records.

\section{Inclusion and exclusion criteria}

Quantitative studies were evaluated for eligibility based on the following selection criteria: (a) early defined BF interventions or exposures targeting ethnic/racial minority women (i.e., at least $70 \%$ in the sample, or reporting analyses broken down by ethnic/racial group) living in the U.S. or any of its territories and conducted during pregnancy, perinatally and/or during the postpartum period; (b) targeting healthy pregnant women with a full-term singleton healthy baby and/or postpartum women; and (c) reporting on one or more of the following BF outcomes: BF initiation, EBF during the first 6 months or any BF within the first year of the infant's life. Studies were excluded from the SR if they (a) did not target minority women (i.e. if less than $70 \%$ of the sample were minority women) or did not conduct analyses of BF outcomes by ethnic/racial group; (b) were not conducted in the U.S. or any of its territories; (c) targeted or included $>10 \%$ of mothers classified as having a high risk pregnancy; (d) focused on women carrying more than one baby or having a preterm baby; or (e) were published before January 2009.

\section{Study selection process}

The records screening process was done using Covidence online software [40]. To ensure consistency across study, three researchers (SSP, AHF, MA) independently screened the first 200 abstracts and screening differences were resolved through a consensus process facilitated by two co-authors (KN and RPE). Then, the operationalization of the inclusion criteria was finalized. The remaining abstracts were divided and independently reviewed by the three co-authors (SSP, AHF, MA). Consensus was reached on the papers that were eligible for a full text review $(n=315)$. The lead author (SSP) reviewed all full text articles while the two co-authors (AHF, MA) each independently reviewed half to ensure each article was reviewed twice. Discrepancies among SSP and AHF or MA were resolved through a consensus group approach as well as with support from the senior author (RPE).

\section{Data extraction}

Data extraction was led by two reviewers (SSP and AHF) with support from two co-authors (MA and RPE). A total of 60 studies met final eligibility and data were extracted for study aim, design, recruitment procedure, methods, intervention characteristics (level of socioecological model addressed), description of intervention or exposure, outcomes, results, and conclusion. Included studies were then organized and presented by socio-ecological model level $[29,30]$.

\section{Quality assessment and risk of bias}

The Grades of Recommendation, Assessment, Development, and Evaluation (GRADE) was used to assess the quality of evidence. GRADE is a study quality assessment approach that follows a standardized method, it is based on an in-depth assessment of different study design risk of bias parameters to classify the quality of evidence as either high, moderate, low or very low. GRADE was used to assess the quality of randomized controlled trials (RCT), quasi-experimental studies, or observational studies according to prespecified criteria [41]. The risk of bias for RCT's was based on the following criteria: randomization procedures, lack of blinding, lack of allocation concealment, incomplete accounting of participants and outcome events. All RCTs were initially ranked as high quality and then could be downgraded based on the extent of the risk of bias. Observational studies were initially ranked as being of low quality but could be upgraded or downgraded based on risks of bias (which focused on measurement of exposures and outcomes, adjustment of confounding factors, statistical analysis, and attrition rate). A similar approach was used for quasi-experimental studies but grading also took into account the appropriateness of the comparison group for addressing confounding. Each study was graded by at least two of the authors (SSP, RPE, AHF). Prior to grading we ensured that the three co-authors were standardized against each other on assigning a quality score to each study based on the risk of bias assessment. The lead author first graded 10 studies and the two other co-authors reviewed the same 10 (5 studies each). The team then met to compare and confirm their consensus on grading scores across studies.

\section{Results}

\section{Literature search}

As shown in the PRISMA flow chart (Fig. 1) a total of 5978 articles were initially identified. Once 66 duplicates were removed, the titles and abstracts of the remaining 5912 articles were screened for SR inclusion and exclusion criteria. As a result, 5597 were eliminated from further consideration. The remaining 315 articles were selected for full-text screening. Of these, 243 articles were excluded in the first phase of full-text screening and subsequently 12 additional articles were excluded while conducting data extraction. Thus, a total of 60 studies met the inclusion criteria for this review. The detailed data 


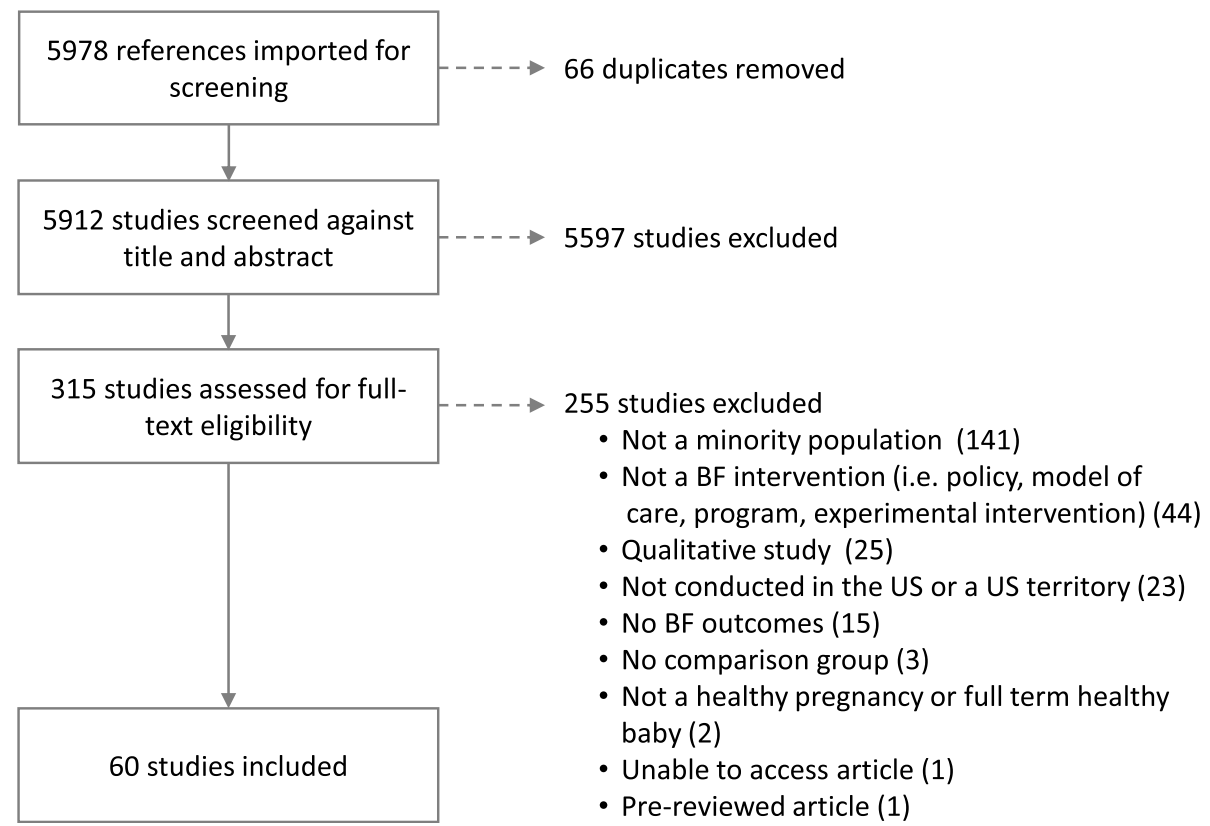

Fig. 1 Systematic review PRISMA flow chart; breastfeeding interventions among women of color in the U.S.

extraction information for each study can be found in online supplementary material 2 .

\section{Study characteristics}

The final set of 60 articles were based on studies with randomized $(n=25)$, observational $(n=24)$, quasiexperimental $(n=9)$ and cross-sectional $(n=2)$ designs. The articles focused in populations that were multiethnic/racial $(n=22)$, only Hispanic $(n=24)$, only Black $(n=13)$, and only American Indian $(\mathrm{n}=1)$.

Since BF decision and practices are affected from the proximal to the distal environments surrounding women, infants, and their families, the socioecological framework was used to examine the relationship between BF intervention/exposures and BF outcomes among minority populations. The level of the socioecological at which the intervention was placed was chosen based on the institution that would be expected to manage the intervention if it were to be scaled up. For example, Baby Friendly Hospital Initiative (BFHI) interventions are delivered at the individual level and can even be linked to home-based peer counseling services through Step 10 of the BFHI. However, at the end of the day, the delivery of BFHI depends on health care facilities. Hence, BFHI studies were classified at the community level of the socioecological model under health care facilities. Following this reasoning, the articles included in this systematic review (SR) were classified as part of the a) macrosystem/policy level $(n=6)$; b) community level (including healthcare organizations $(n=34)$, WIC program $(n=9)$ and community organization or public health institution $(n=8))$; or c) interpersonal level $(n=3)$ (Fig. 2). Thus, findings of this review are synthesized at these levels of the socioecological framework.

\section{Macrosystem/policy level}

The six studies identified as part of the macrosystem/ policy level included analyses of the impact of BF policies among racial and ethnic groups. Four had pre/ post observational designs, one retrospective and one was quasi-experimental. Their quality was graded as moderate $(n=1)$ or low $(n=5)$ (Table 2).

Three studies evaluated the association between BF promoting laws and BF initiation and duration (one at federal policy level, two at state level) [42-44]. Two reported positive outcomes on BF practices, especially among minority women [42, 43]. An observational study by Kapinos et al. [42] focused on the influence of the mandated coverage of lactation support services under the Affordable Care Act (ACA). After ACA was enacted, Black/African-American (AA) women and American Indian/Alaska Natives (AI/AN) were more likely to initiate $\mathrm{BF}$ (by $1-2$ and $1 \%$, respectively) compared to their non-Hispanic White counterparts. A state-level policy study by Hawkins et al. [43] assessed the influence of two maternity protection laws on BF: a) employers providing breaks and space for BF to employees and $\mathrm{b}$ ) BF being permitted in any public or private location. Pregnancy Risk Assessment Monitoring System (PRAM 


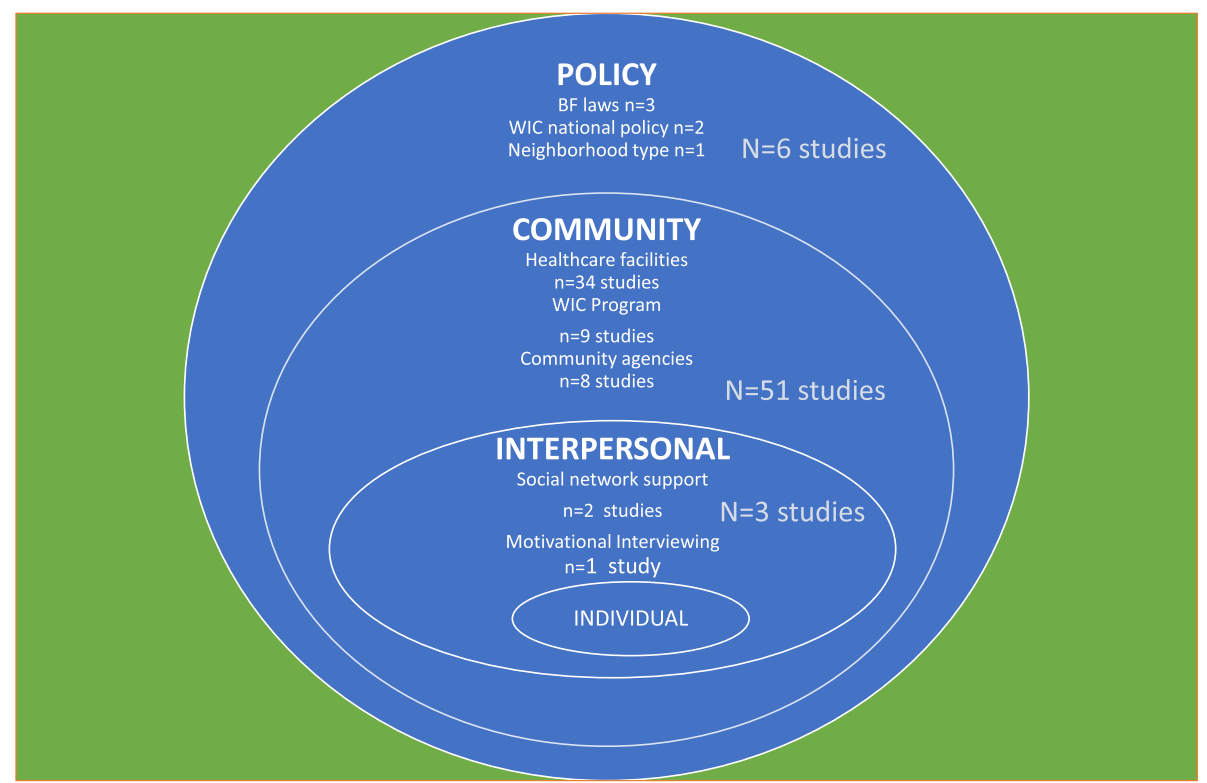

Fig. 2 Breastfeeding studies identified for systematic review by socioecological model level among women of color in the U.S.

S) weighted data (2000-2008) from thirty-two states was used to assess BF initiation and duration before and after policy enactment. For each law, each mother received a code of yes if the law had been in place in the 6 months prior to the delivery of the newborn or no if otherwise, based on the law's effective date. Findings showed that $\mathrm{BF}$ initiation rates were significantly higher in states with laws in place that provided BF break time and private space by employers. While Hispanics had a 5.8 percentage point increase in BF initiation in states where the new law was enacted, this association was not seen among Black mothers. However, a 5.6 percentage point increase on BF initiation was seen among Black women within states with new laws permitting BF in any location.

A pre/post observational study by Smith-Gagen et al. [44] used 2003 to 2010 data from the National Health and Nutrition Examination Survey (NHANES) and assessed the impact of eight BF supportive laws enacted at the state level. The laws examined were: 1 ) exempting BF from public indecency, 2) allowing women to breastfeed in public and private locations, 3) exempting BF women from jury duty, 4) encouraging BF awareness campaigns, 5) allowing a reasonable unpaid breaktime from work for BF mothers to express milk, 6) requiring a sanitary space at work for BF mothers to express milk, 7) permitting workplace pumping, and 8) permitting public BF. Analyses, which were stratified by race/ethnicity, found no differences in ever BF rates by law between racial/ethnic minority groups and non-Hispanic Whites. When examining BF duration, Mexican Americans mothers, compared to non-Hispanic Whites, were
$30 \%$ more likely to breastfeed for at least 6 months in states providing break time from work (AOR, 1.3; 95\% CI, 1.0-1.8). Conversely, compared with non-Hispanic Whites, Black mothers were less likely to breastfeed for at least 6 months in areas with laws protecting break time at work places (AOR, 0.6; 95\% CI, 0.5-0.8), areas providing an exemption for jury duty (AOR, 0.6; 95\% CI, 0.4-0.9), and areas with pumping law enforcement (AOR, 0.6; 95\% CI, 0.5-0.8).

Two observational studies examined the effect of the 2009 Supplemental Nutrition Program for Women, Infants and Children's (WIC's) package on BF practices [45, 46]. Li et al. [45] compared two NHANES crosssectional cohorts (2000-2008 versus 2009-2014) before and after the implementation of the new 2009 WIC package. Among WIC participants, improvements were seen in BF initiation between 2009 and 2014 but not in BF duration at 6 months. A study by Langellier et al. [46] used a pre/post design with data from the Los Angeles WIC triennial survey (2005, 2008 and 2011) to assess the effect of the 2009 WIC package on BF outcomes among WIC participants in Los Angeles County. Findings showed that participants who received the new food package had 2.2 times the odds of initiating $\mathrm{BF}$ $(P<.001), 1.7$ times the odds of exclusively BF at 3 months $(\mathrm{P}<.001)$, and 3.1 times the odds of exclusively $\mathrm{BF}$ through 6 months $(\mathrm{P}<.001)$. No effects were seen on any $\mathrm{BF}$ rates at 3 and 6 months.

The last study, a retrospective observational design by Yourkavitch et al. [47], assessed the relationship between living in neighborhoods with different levels of disadvantage and affluence and BF outcomes. The study 
Table 2 Policy level breastfeeding interventions among women of color in the U.S.

\begin{tabular}{|c|c|c|c|c|c|}
\hline Study & $\begin{array}{l}\text { Study Design/Data } \\
\text { collection }\end{array}$ & Study Population & $\begin{array}{l}\text { Intervention/ } \\
\text { Exposure }\end{array}$ & Outcomes/Results & Grade \\
\hline $\begin{array}{l}\text { Kapinos } \\
\text { et al. [42] } \\
\text { National } \\
\text { data }\end{array}$ & $\begin{array}{l}\text { Design: Pre/post } \\
\text { observational } \\
\text { Data: } 2009-2014 \\
\text { National Vital Statistics } \\
\text { System }\end{array}$ & $\begin{array}{l}N=17,985,584 \text { births; } \\
\text { H: 33.42\%; W: 77.04\%; AA: } \\
\text { 15.72\%; Al: 0.99\%; A/PI: 6.47\% }\end{array}$ & $\begin{array}{l}\text { Before/After Affordable } \\
\text { Care Act (ACA } 2009 \\
\text { versus 2013, } 2009 \\
\text { versus 2014) }\end{array}$ & $\begin{array}{l}\text { ACA implementation associated with AA } \\
\& \text { Al/AN mothers being } 1-2 \% \text { points } \\
\text { more likely than W women to initiate } \\
\text { BF. }\end{array}$ & Low \\
\hline $\begin{array}{l}\text { Hawkins } \\
\text { et al. [43] } \\
\text { PRAMS data }\end{array}$ & $\begin{array}{l}\text { Design: Quasi- } \\
\text { experimental } \\
\text { Data:2000 \& } 2008 \\
\text { Pregnancy Risk } \\
\text { Assessment } \\
\text { Monitoring System } \\
\text { (PRAMS) } 32 \text { states. }\end{array}$ & $\begin{array}{l}N=349,780 \text { mothers; } 2000- \\
\text { 2008: } \\
\text { W:55.7-53.3\%; H:12.4-15.1\%; AA: } \\
\text { 18-16.4\%; Other:13.6-15\% }\end{array}$ & $\begin{array}{l}\text { Before/After BF state } \\
\text { laws: 1) worksite } \\
\text { breaktime and private } \\
\text { space for BF } \\
\text { 2) BF anywhere }\end{array}$ & $\begin{array}{l}\mathrm{H} \text { mothers had } 5.8 \% \text {-point increase in } \mathrm{BF} \\
\text { initiation in states with worksite laws. AA } \\
\text { mothers had } 5.6 \% \text {-point increase in BF } \\
\text { initiation in states with laws for BF in } \\
\text { any location. }\end{array}$ & Low \\
\hline $\begin{array}{l}\text { Smith- } \\
\text { Gagen et al. } \\
{[44]} \\
\text { National } \\
\text { data }\end{array}$ & $\begin{array}{l}\text { Design: Pre/Post } \\
\text { observational } \\
\text { Data: } 2003-2010 \text { U.S. } \\
\text { NHANES linked to } \\
\text { Policy data }\end{array}$ & $\begin{array}{l}N=3132 \\
A A=609, H=1078 \\
W=1445\end{array}$ & $\begin{array}{l}\text { Before/After } \\
8 \mathrm{BF} \text { protection laws }{ }^{\mathrm{a}}\end{array}$ & $\begin{array}{l}\text { At } 6 \text { mo AA were half as likely to BF for } \\
\text { jury duty exemption; } \mathrm{H} \text { were more likely } \\
\text { to BF with break time from work } \\
\text { /pumps access when compared with W. }\end{array}$ & Low \\
\hline $\begin{array}{l}\text { Li et al. [45] } \\
\text { National } \\
\text { data }\end{array}$ & $\begin{array}{l}\text { Design: Pre/Post } \\
\text { Observational } \\
\text { Data:2000-2014 } \\
\text { NHANES data of WIC } \\
\text { eligible }<5 \text { y old } \\
\text { children. }\end{array}$ & $\begin{array}{l}\text { 2000-2008: } N=2770 ; W= \\
25.31 \% ; A A=22.20 \% ; H= \\
45.92 \% .2009-2014: N=1538 ; \\
W=22.63 \% ; A A=27.63 \% ; H= \\
39.92 \%\end{array}$ & $\begin{array}{l}\text { WIC eligible } \\
\text { participants and non- } \\
\text { participants before } \\
\text { and after } 2009 \text { WIC } \\
\text { package. }\end{array}$ & $\begin{array}{l}\text { 2009-2014 BF initiation rates improved } \\
\text { for WIC participants, and the differences } \\
\text { among non-participant became non sig- } \\
\text { nificant as it was in 2000/2008. No effect } \\
\text { on BF duration. }\end{array}$ & Moderate \\
\hline $\begin{array}{l}\text { Langellier } \\
\text { et al. [46] } \\
\text { WIC survey }\end{array}$ & $\begin{array}{l}\text { Design: Pre/post } \\
\text { observational } \\
\text { Data: WIC LA County } \\
\text { Survey }\end{array}$ & $\begin{array}{l}N=5524 \text {; in } 200584.9 \% \mathrm{H} \text {; in } \\
201180 \% \mathrm{H}\end{array}$ & $\begin{array}{l}2009 \text { WIC Package } \\
\text { revisions; } 2011 \\
\text { vs. } 2005 \text { and } 2008\end{array}$ & $\begin{array}{l}\text { In } 2011 \text { BF initiation, EBF for } 3 \text { mo., and } \\
\text { EBF at } 6 \text { mo. significantly increased. No } \\
\text { effect on Any BF at } 3 \& 6 \text { mo }\end{array}$ & Low \\
\hline $\begin{array}{l}\text { Yourkavitch } \\
\text { et al. [47] } \\
\text { Data sets }\end{array}$ & $\begin{array}{l}\text { Design: Retrospective } \\
\text { Data: New Jersey birth } \\
\text { certificate and medical } \\
\text { records data }\end{array}$ & $\begin{array}{l}\text { EBF sample, } N=26,287 \\
W=60 \% ; A A=10 \% ; H=20 \% ; A \\
P I=10 \% . A n y \quad B F, N=54,117 \\
W=43 \% ; A A=13 \% ; H=33 \% ; A \\
P I=12 \%\end{array}$ & $\begin{array}{l}\text { Neighborhood } \\
\text { (NBHD) disadvantage } \\
\text { versus affluence }\end{array}$ & $\begin{array}{l}\text { EBF decreased as NBHD disadvantage } \\
\text { increased only for Asian, AA, and } \mathrm{H} \text {. EBF } \\
\text { increased as NBHD affluence increased } \\
\text { for } \mathrm{H} \text { and } \mathrm{W} \text {. Any BF decreased as NBHD } \\
\text { disadvantage increased among } \mathrm{H} \text { and } \\
\text { W. }\end{array}$ & Low \\
\hline
\end{tabular}

a8 laws: 1) BF exempt from indecency laws, 2) laws allowing women to $\mathrm{BF}$ in public/private locations, 3) laws to exempt $\mathrm{BF}$ women from jury duty, 4) laws to encourage $B F$ awareness campaigns, 5) laws allowing a reasonable unpaid breaktime from work to express milk, 6) laws requiring a sanitary space at work to express milk, 7) enforcement of workplace pumping laws and 8) enforcements of public BF laws. Abbreviations: $A A$ African American; $A / P I$ Asian/ Pacific Islander; H Hispanic; W White; NBHD Neighborhood; WIC, Special Supplemental Nutrition Program for Women, Infants and Children; NHANES National Health and Nutrition Examination Survey; $B F$ breastfeeding; $E B F$ Exclusive breastfeeding

used 2006 birth certificate data linked to census tracks in New Jersey. Findings showed that the probability of EBF was lower as neighborhood disadvantage increased for all populations (Asian, Black, Hispanic) except nonHispanic White women. As neighborhood affluence improved, the probability of EBF increased among Hispanic and non-Hispanic White women only while the odds of any $\mathrm{BF}$ increased for all racial groups except Hispanic women.

These findings suggest that BF protection laws such as the provision of work breaks and space by employers seem to benefit Hispanic women the most, and laws protecting $\mathrm{BF}$ in private and public places protect Black women more. More needs to be understood about the effect of these laws among the different racial/ ethnic minorities. Changes in federal food assistance policies may also positively influence BF outcomes among racial/ ethnic minority populations as intended by the changes made to the WIC BF packages in 2009 to incentivize
EBF. However, effect sizes tended to be small implying that, in addition to policies, the delivery of BF programs at the community level is needed. Most studies were observational of moderate $(n=1)$, and low $(n=4)$ quality, and the quasi-experimental study was classified as low quality as well. The studies in the organizational/ community level of the socioecological model are presented in the following section.

\section{Organizational/community level}

Most (85\%) of the 60 interventions included in this review were conducted at the organizational/community level $(n=51)$. Of these, 33 were implemented at healthcare institutions, 9 were WIC programs, and 9 were based at community maternal and child health programs. Interventions at healthcare institutions are divided into implementation periods: pregnancy $(n=5)$; in the maternity ward $(n=7)$; pregnancy and postpartum $(n=5)$; pregnancy, delivery and post-partum 
$(n=6)$; post-partum [8]. The results are presented based on these implementation periods.

\section{Healthcare interventions Prenatal}

There were five BF studies, all observational designs, conducted primarily during pregnancy [48-52]; three were with women enrolled in the Centering Pregnancy Model (CPM) and had mixed results. The first observational prospective study conducted by Chae et al. [48] in a prenatal New Jersey clinic among low-income, predominantly minority women found that women receiving CPM prenatal care were two times more likely to be $\mathrm{BF}$ at their postpartum visit $(\mathrm{OR}=2.9, p=$ 0.001) compared with those receiving standard prenatal care. The authors suggest that the social and emotional peer support provided by CPM may explain this finding. By contrast, a second study with a prospective observational design conducted by Robertson et al. [49] in Georgia with Hispanic women receiving CPM prenatal care did not find significant differences on BF outcomes compared with standard prenatal care. However, it should be noted that both studies had high attrition rate. Unexpectedly, a third study with retrospective observational design conducted by Trudnak et al. [50] among Hispanic women receiving CPM prenatal care found that they were more likely to be feeding formula at their newborn visit.

An observational prospective study by Farr et al. [51], conducted with African American women, examined the effect of two 5-10 min iPad prenatal interventions on BF outcomes. One intervention focused on helping the mother identify a supportive BF champion (Champion intervention) while the other provided BF information following a frequently asked questions approach (Positive messaging intervention). The interventions had the most in-hospital impact on EBF rates among women not intending to EBF during pregnancy. However, findings need to be interpreted with caution as the study did not include a comparison group with no intervention and mothers delivered at a Baby Friendly Hospital (BFH). Lastly, an observational study by Louis-Jacques et al. [52] assessed the effect of a prenatal basic educational intervention focused on medications use and lactation among predominantly Hispanic mothers with no contraindications for BF. Findings showed the intervention was not effective in improving BF outcomes since women taking medication were three and four times more likely to mix feed or feed formula at 2-4 week and 6-8 week post-partum respectively.

All studies included in this section were nonexperimental with most interventions focusing on various aspects of prenatal care or were simple BF interventions. None of the intervention were adapted or tailored specifically to minority women. Studies were of low $(n=$ 3 ) or very low $(n=2)$ quality (Table 3$)$.

\section{Maternity Ward}

An observational study conducted by the Communities and Hospitals Advancing Maternity Practices initiative (CHAMPS) between 2014 and 2017 found that the implementation of the Ten Steps from the Baby Friendly Hospital Initiative (BFHI) improved BF outcomes and reduced BF disparities in 4 Southern States. Using evaluation data from 31 of 33 participating hospitals (7 in Louisiana, 17 in Mississippi, 2 in Tennessee, 5 in Texas), findings showed that, as BFHI implementation advanced, the proportion of women who experienced rooming-in and skin-to- skin contact after delivery increased. Breastfeeding initiation rates increased during the same period from 66 to $75 \%(p<0.05)$, and EBF rates increased from 34 to $39 \%$ ( $p<0.05)$. Furthermore, BF initiation rate inequities for non-Hispanic Black women declined by 9.6 percentage points when compared against non-Hispanic White women. In 2017, 91\% of the hospitals participating in the project were pursuing BFH designation and, by 2018, 14 hospitals had achieved their BFH designation [53]. Two articles examined the association between maternity care practices (MCP) and BF outcomes by race/ethnicity using PRAMS survey data [54, 55]. A retrospective observational study by Ahluwalia et al. [54] analyzed 2004-2006 PRAMS survey data from 11 states and NY City to evaluate the effect of MCP on BF duration ( $\geq 10$ weeks vs. $<10$ weeks). Different MCPs were associated with BF duration among racial/ethnic groups. BF within the first hour postpartum was associated with BF duration of $\geq 10$ weeks among Black (OR 1.62; 95\% CI 1.20-2.19) and non-Hispanic White women $(1.36 ; 1.16-1.58)$. Likewise, BF on demand was significantly associated with BF duration of $\geq 10$ weeks among Black (1.72; 1.28--2.31) and Hispanic women $(1.49 ; 1.15-1.91)$. Across all racial groups, the number of newborns receiving only breastmilk at the hospital was associated with BF for $\geq 10$ weeks. Three MCPs were also associated with less likelihood of BF for $\geq 10$ weeks among Black women including: giving pacifier at the hospital $(0.58 ; 0.44-0.77)$, receiving $\mathrm{BF}$ information $(0.62 ; 0.34-1.12)$, and receiving help from hospital staff with BF (0.63; 0.46-0.88). Among Hispanic women, receiving a gift pack containing infant formula was associated with less likelihood of $\mathrm{BF} \geq 10$ weeks (0.67; 0.50-0.90). Among non-Hispanic White women, giving pacifier at the hospital was identified as a risk factor for longer BF duration (0.76; 0.660.87). The authors concluded that in order to improve BF outcomes among all women there is a need 
Table 3 Community level healthcare facility breastfeeding interventions among women of color in the U.S. : Prenatal

\begin{tabular}{|c|c|c|c|c|c|}
\hline $\begin{array}{l}\text { Study/ } \\
\text { Setting }\end{array}$ & $\begin{array}{l}\text { Study Design/ } \\
\text { Data } \\
\text { collection }\end{array}$ & Population & Intervention/Exposure & Outcomes/ Results & Grade \\
\hline $\begin{array}{l}\text { Chae et al. } \\
\text { [48] } \\
\text { Family } \\
\text { Medicine } \\
\text { Outpatient } \\
\text { Clinic }\end{array}$ & $\begin{array}{l}\text { Design: } \\
\text { Prospective } \\
\text { Data: } 3 \text { rd } \\
\text { prenatal } \\
\text { trimester, 6-8 } \\
\text { wks surveys }\end{array}$ & $\begin{array}{l}\text { Center Pregnancy } \\
\text { Model (CPM) } \\
(n=120) ; 15 \% \mathrm{~A} ; 28.3 \% \\
\text { AA } \\
30 \% \mathrm{H}, 26.7 \% \mathrm{~W} \\
\text { Standard Care (SC) } \\
(n=221) ; 16.7 \% \mathrm{~A} ; \\
20.3 \% \mathrm{AA} ; 34.8 \% \mathrm{H} ; \\
26.7 \% \mathrm{~W}\end{array}$ & $\begin{array}{l}\text { CPM: Via health care } \\
\text { providers; } 10 \text { prenatal and } 1 \\
\text { p.p. sessions } \\
\text { SC group: Individual care }\end{array}$ & $\begin{array}{l}\text { CPM Participants }>2 \text { times more likely to BF at p.p. } \\
\text { visit }\end{array}$ & Low \\
\hline $\begin{array}{l}\text { Robertson } \\
\text { et al. [49] } \\
\text { Hospital } \\
\text { based } \\
\text { prenatal } \\
\text { clinic }\end{array}$ & $\begin{array}{l}\text { Design: Two } \\
\text { group, pre/post } \\
\text { observational } \\
\text { Data: prenatal } \\
\text { and p.p. } \\
\text { surveys }\end{array}$ & $\begin{array}{l}\mathrm{CPM} \mathrm{n}=24 \mathrm{H} \\
\mathrm{SC} n=25 \mathrm{H}\end{array}$ & $\begin{array}{l}\text { Midwife care to both groups. } \\
\text { CPM: first } 4 \text { pregnancy } \\
\text { months groups met once a } \\
\text { month, then biweekly until } \\
\text { delivery. } \\
\text { SC: Individual prenatal care }\end{array}$ & NS BF differences at 6 weeks p.p. & $\begin{array}{l}\text { Very } \\
\text { low }\end{array}$ \\
\hline $\begin{array}{l}\text { Trudnak } \\
\text { et al. [50] } \\
\text { Health } \\
\text { Department } \\
\text { Clinics }\end{array}$ & $\begin{array}{l}\text { Design: } \\
\text { Retrospective } \\
\text { Data: Chart } \\
\text { review }\end{array}$ & $\begin{array}{l}\mathrm{CPM} \mathrm{n}=240 \mathrm{H} \\
\mathrm{SC} n=240 \mathrm{H}\end{array}$ & $\begin{array}{l}\text { CPM: prenatal group care } \\
\text { SC: individual care }\end{array}$ & At 6 wks p.p. CPM participants more likely to FF. & Low \\
\hline $\begin{array}{l}\text { Farr et al. } \\
{[51]} \\
\text { Women's } \\
\text { Health } \\
\text { Clinics }\end{array}$ & $\begin{array}{l}\text { Design: } \\
\text { Observational } \\
\text { Data: Chart } \\
\text { review }\end{array}$ & $\begin{array}{l}\text { Champion iPad app } \\
n=132 ; 96.2 \% \text { AA } \\
\text { Positive messaging } \\
\text { iPad app } \\
n=111 \text { participants. } \\
90.8 \% \text { AA, }\end{array}$ & $\begin{array}{l}\text { Champion app } \\
\text { helped mothers identify } \\
\text { supportive BF champion. } \\
\text { Positive messaging app } \\
\text { offered BF information with } \\
\text { picture; FAQ format. }\end{array}$ & $\begin{array}{l}\text { For both apps, proportion of mothers who } \\
\text { intended EBF prenatally more likely to EBF in- } \\
\text { hospital increased (vs. those not intending EBF) }\end{array}$ & $\begin{array}{l}\text { Very } \\
\text { low }\end{array}$ \\
\hline $\begin{array}{l}\text { Louis- } \\
\text { Jacques } \\
\text { et al. [52] } \\
\text { Prenatal } \\
\text { clinics }\end{array}$ & $\begin{array}{l}\text { Design: } \\
\text { Prospective } \\
\text { Data: Pre/post; } \\
\text { BF survey data } \\
\text { at 2-4 and 6-8 } \\
\text { wks p.p. }\end{array}$ & $N=121 ; 63.6 \% \mathrm{H}$ & $\begin{array}{l}\text { Prenatal BF, medication and } \\
\text { substance abuse education; } \\
\text { via Doulas and IBCLC. }\end{array}$ & $\begin{array}{l}\text { Women using medications at } 2-4 \text { and } 6-8 \text { weeks } \\
\text { p.p. were less likely to EBF and more likely to mix } \\
\text { feed or FF vs. mothers not taking medication } 2-4 \\
\text { wks p.p. and } 6-8 \text { weeks p.p. }\end{array}$ & Low \\
\hline
\end{tabular}

Abbreviations: AA African American; A Asian; $H$ Hispanic; $W$ White; p.p. postpartum; CPM Center Pregnancy Model; SC standard care; NS not significant; $B F$ breastfeeding, EBF exclusive breastfeeding; FF formula feeding; IBCLC Board Certified Lactation Consultant; app application

to better assess and understand the impact of MCP on women from different racial and ethnic backgrounds [54]. Another observational study by Sebastian et al. [55] used PRAMS survey data from New Mexico (2012-2014) and found that, compared with White women, Native American and Hispanic women were less likely to report BF while at the hospital and report receiving a phone number for BF support. Across all racial groups, offering only breastmilk at the hospital and BF on demand were positively associated with $\mathrm{BF}$ at 2 months. Hispanic women had the lowest BF rates compared with non-Hispanic White or Native American women. However, Spanishspeaking Hispanic women had similar BF rates at 2 months as non-Hispanic White women. Thus, findings suggest that BF services at hospitals should account for acculturation level among the Hispanic women that they serve.

Four studies supported the importance of $\mathrm{BFH}$ practices on BF outcomes. Nobari et al. [56] used 20121014 LA County triennial WIC random survey data and found that children born in $\mathrm{BFH}$, compared to those born in non-BFH, were: (a) more likely to be EBF at 1 and 3 months, (b) more likely to have been breastfed only at the hospital, and (c) less likely to have been given formula at discharge. Consistent with these findings, another retrospective study by Jung et al. [57] using 20082017 data from same survey found that the uptake of $\mathrm{BFH}$ practices coincided with significant increases in any $\mathrm{BF}$ and EBF outcomes among WIC infants in Los Angeles County. A third study, an observational prospective cohort study conducted by Linares et al. [58] with Hispanic immigrant women at a Kentucky Hospital, found that skin-to-skin contact (SSC) at birth was associated with higher rates of EBF at discharge compared with those that did not have SSC $(86.3 \%$ vs. $13.7 \%, p<$ 0.001 ), and this was independent of the type of delivery. Lastly, an observational prospective study by Ekambaram et al. [59] assessed the effect of implementation of a pacifier limiting in-hospital policy on BF outcomes. The study, conducted with predominantly African American women, found that the policy of limiting pacifier use at the birthing hospital was associated with higher EBF rates at hospital discharge, but not with BF rates at one 
Table 4 Community level healthcare facility breastfeeding interventions among women of color in the U.S.: Maternity ward

\begin{tabular}{|c|c|c|c|c|c|}
\hline $\begin{array}{l}\text { Study/ } \\
\text { Setting }\end{array}$ & $\begin{array}{l}\text { Study Design/ } \\
\text { methods }\end{array}$ & Study Population & Exposure/Intervention & Outcomes and Results & Grade \\
\hline $\begin{array}{l}\text { Merewood } \\
\text { et al' [53] } \\
\text { Maternity } \\
\text { Hospitals }\end{array}$ & $\begin{array}{l}\text { Design: Prospective } \\
N=33 \text { hospitals } \\
\text { Data: } 2014-17 \\
\text { hospital data }\end{array}$ & $\begin{array}{l}\text { 4 Southern states; } N=31 \\
\text { hospitals; } N=210-3953 \\
\text { records; } 2-85 \% \text { AA; } 0-90 \% \\
\text { H, 5-81\% W }\end{array}$ & at least 3 BFH steps & $\begin{array}{l}\text { BF initiation and EBF increased. } \\
\text { Inequities in BF initiation between AA } \\
\text { and } \mathrm{W} \text { decreased by } 9.6 \% \text { points } \\
14 \text { hospitals received BFH designation. }\end{array}$ & Low \\
\hline $\begin{array}{l}\text { Ahluwalia } \\
\text { et al. [54] } \\
\text { PRAMS } \\
\text { survey }\end{array}$ & $\begin{array}{l}\text { Design: } \\
\text { Retrospective } \\
\text { Data: 2004-2006 } \\
\text { Pregnancy Risk } \\
\text { Assessment } \\
\text { Monitoring System } \\
\text { (PRAMS) survey }\end{array}$ & $\begin{array}{l}N=49,135 \text { women in } 11 \\
\text { states and NY City } 56.5 \% \text { W; } \\
14.4 \% \mathrm{AA} \text {; } \\
23.4 \% \mathrm{H}\end{array}$ & Maternity Care Practices (MCPs) ${ }^{a}$ & $\begin{array}{l}B F \geq 10 \text { weeks associated with: early BF } \\
\text { initiation (AA \& W); BF on demand (AA } \\
\& H) \text {; only breastmilk in hospital (all). } \\
\text { BF }<10 \text { associated with: in-hospital } \\
\text { pacifier (AA \& W), BF support from hos- } \\
\text { pital staff (AA); gift formula pack (H) }\end{array}$ & Low \\
\hline $\begin{array}{l}\text { Sebastian } \\
\text { et al. [55] } \\
\text { PRAMS } \\
\text { survey }\end{array}$ & $\begin{array}{l}\text { Design: } \\
\text { Retrospective } \\
\text { Data: 2012-2014 } \\
\text { New Mexico PRAMS } \\
\text { survey }\end{array}$ & $\begin{array}{l}N=4035 \text { Women who } \\
\text { initiated BF; 8.4\% Spanish- } \\
\text { speaking } \mathrm{H} ; 46 \% \text { English- } \\
\text { speaking } \mathrm{H} ; 13.3 \% \text { Al; } 28.2 \% \\
\text { W }\end{array}$ & $\begin{array}{l}\text { Supportive vs unsupportive BF } \\
\text { MCPs }\end{array}$ & $\begin{array}{l}\text { Al and } \mathrm{H} \text { less likely to report } \mathrm{BF} \text { at the } \\
\text { hospital and receiving phone number } \\
\text { for } \mathrm{BF} \text { support. English-speaking } \mathrm{H} \\
\text { least likely to } \mathrm{BF} \text {, only breast milk, stay- } \\
\text { ing in the same room, more likely to } \\
\text { receive a gift formula pack. }\end{array}$ & Low \\
\hline $\begin{array}{l}\text { Nobari et al. } \\
{[56]} \\
\text { WIC survey }\end{array}$ & $\begin{array}{l}\text { Design: } \\
\text { Observational } \\
\text { Data: Los Angeles } \\
\text { County (LAC) WIC } \\
\text { Survey (2008, 2011, } \\
\text { 2014) }\end{array}$ & $\begin{array}{l}N=1661 \text { children } \leq 2 \text { y old } \\
\text { born at LAC hospitals }(B F H ; \\
\text { BFH in process; not BFH); } \\
82 \% \mathrm{H}\end{array}$ & $\begin{array}{l}\text { Exposure to any of } 3 \text { MCPs: Only } \\
\text { breastmilk at hospital; Hospital } \\
\text { gave gift formula; provided } \\
\text { phone number for BF support. }\end{array}$ & $\begin{array}{l}\text { Designated and in-process BFH associ- } \\
\text { ated with EBF at } 1 \text { and } 3 \text { mo. }\end{array}$ & Low \\
\hline $\begin{array}{l}\text { Jung et al. } \\
\text { [57] } \\
\text { WIC survey }\end{array}$ & $\begin{array}{l}\text { Design: pre/post } \\
\text { Observational } \\
\text { Data: WIC triennial } \\
\text { survey }(2008,2011 \text {, } \\
\text { 2014, 2017) }\end{array}$ & $\begin{array}{l}N=6449 \text { eligible clients. } \\
74 \% \mathrm{H}\end{array}$ & $\begin{array}{l}\text { Exposure to any of } 3 \text { MCPs: Only } \\
\text { breastmilk at hospital; Hospital } \\
\text { gave gift formula; provided } \\
\text { phone number for BF support. }\end{array}$ & $\begin{array}{l}\text { Children born in a BFH (designated or } \\
\text { in process) significantly higher in } 2017 \\
\text { vs. 2014. Less formula packs in } 2017 . \\
\text { Any BF \& EBF at } 1 \text { mo higher in } 2017 \text {. } \\
\text { BF at } 6 \text { mo and EBF at 1, 3, and } 6 \text { mo } \\
\text { associated with only BF at hospital. }\end{array}$ & Low \\
\hline $\begin{array}{l}\text { Linares et al. } \\
\text { [58] Medical } \\
\text { chart }\end{array}$ & $\begin{array}{l}\text { Design: Prospective } \\
\text { Data: Pregnancy } \\
\text { survey, medical } \\
\text { charts, } 1 \text { mo p.p. }\end{array}$ & $N=97 \mathrm{H}$; Central Kentucky & $\begin{array}{l}\text { Skin-to-Skin Contact (SSC) } \\
\text { SSC vs. non-SCC }\end{array}$ & $\begin{array}{l}\text { Higher EBF at discharge and at 1-mo } \\
\text { p.p.; not associated with EBF 1-mo p.p. }\end{array}$ & Low \\
\hline $\begin{array}{l}\text { Ekambaram } \\
\text { et al' [59] } \\
\text { Medical } \\
\text { chart }\end{array}$ & $\begin{array}{l}\text { Design: Pre/post } \\
\text { observational } \\
\text { Data: medical charts, } \\
1 \text { mo p.p. phone } \\
\text { survey }\end{array}$ & $\begin{array}{l}N=283 \text { pre; } N=272 \text { post; } \\
\text { Philadelphia, Pennsylvania; } \\
100 \% \text { AA }\end{array}$ & $\begin{array}{l}\text { Pacifier policy: not offering } \\
\text { pacifier at the clinics and } \mathrm{BF} \\
\text { education. }\end{array}$ & $\begin{array}{l}\text { Intervention associated with EBF on } \\
\text { day of discharge; no differences on } \\
\text { EBF at } 1 \text { mo p.p. }\end{array}$ & $\begin{array}{l}\text { Very } \\
\text { Low }\end{array}$ \\
\hline
\end{tabular}

a1.Hospital staff gave me BF information 2. My baby stayed in the same room with me at the hospital, 3.1 breastfed my baby in the hospital (not included in analysis), 4. I breastfed my baby in the first hour after my baby was born, 5.Hospital staff helped me learn how to breastfeed, 6. My baby was fed only breast milk at the hospital, 7. Hospital staff told me to breastfeed whenever my baby wanted, 8 . The hospital gave me a gift pack with formula, 9. The hospital gave me a telephone number to call for help with BF, 10. My baby used a pacifier in the hospital. Abbreviations: $A A$ African American; $H$ Hispanic; $A l$ American Indian; $W$ White; $B F H$ Baby Friendly hospital; $M C P$ s maternity care practices; p.p. postpartum; $E B F$ exclusive breastfeeding; $B F$ breastfeeding

month postpartum. However, this study must be interpreted with caution as, during the time that the pacifier policy was implemented, additional BFH training for all maternity hospital health also occurred.

Overall, these studies suggest that MCP based on The Ten Steps, were positively associated with BF outcomes, and positively impacted minority populations by decreasing disparities. They also suggest that the influence of these practices on BF outcomes may be modified by race/ethnicity, calling for $\mathrm{BF}$ services to account for the needs and wants of different racial/ethnic groups. These seven studies were of low $(n=6)$ or very low $(n=1)$ quality (Table 4).

\section{Prenatal and post-partum interventions}

Messito et al. [60] conducted a randomized controlled study with Hispanic women to evaluate the impact of the Starting Early Program (StEP), which focused on building mother's responsive infant feeding behaviors skills and knowledge through a combination of group sessions and individual counseling during pregnancy and post-partum. StEP was associated with an $50 \%$ increase in continued BF at 10 months. A randomized intervention by Kao et al. [61] sought to prevent post-partum depression among a diverse population of low-income women. Within the intervention, nurses taught pregnant women the importance of self-care and being assertive (e.g. asking for help and support to be able to sustain BF) and offered a 
support post-partum session. While no differences were found between intervention and standard care groups regarding BF initiation, intervention mothers had a significantly longer $\mathrm{BF}$ duration compared to standard care mothers (54 vs. 21 days, respectively $p=0.013$ ).

Watt et al. [62] conduced a quasi-experimental intervention among low-income Hispanic women that provided prenatal and post-partum nutrition education plus cooking demonstration, lactation counseling classes, and farmer's market vouchers. Findings showed that the intervention improved BF rates compared to the comparison group $(79.2 \%$ vs. $54.2 \%$, respectively). Yet, this difference was not statistically significant $(p=0.66)$ which was likely due to the small sample size (only about $30 \%$ of participants participated in the post-partum component) and that the intervention focused more on improving overall family nutrition than just BF. A separate quasiexperimental pre/post implementation study conducted by Schreck et al. [63] assessed the influence of prenatal BF education and hospital-based BF postpartum support groups among a predominantly African American women. Improvements in BF initiation rates $(71.9 \%$ post-intervention versus $51.5 \%$ at baseline $(p<0.0001))$ were seen, but no associations were found with BF duration. Lastly, Efrat et al. [64] conducted a randomized study among Hispanic women during pregnancy and post-partum. A phone-based intervention was delivered by lactation educators who were undergraduate students with no BF experience. The intervention did not impact $\mathrm{BF}$ outcomes although the authors concluded that their intervention was a cost-effective strategy to in-person peer counselors (PCs).

Findings from two of the studies reviewed in this section $[60,61]$ suggest that the prenatal and postpartum interventions that were most effective at improving BF outcomes were those that taught skills to mother to improve responsive infant feeding or maternal self-care behaviors even though in both studies these BF was a secondary outcome. The 5 studies reviewed in this section were of moderate $(n=1)$, low $(n=2)$ or very low $(\mathrm{n}=2)$ quality (Table 5$)$.

\section{Prenatal, hospital and post-partum interventions}

Six randomized trials conducted during prenatal, hospital, and the postpartum periods found mixed results. Wambach et al. [65] assessed the impact of an intervention with low-income, primiparous predominantly African American adolescents (15-18 years old) delivered by a team of a nurse (who also was a lactation consultant) and a peer educator. This intervention lasted from second trimester of pregnancy until 4th week postpartum and had a positive impact on BF duration but not on BF initiation or EBF. Edwards et al. [66] conducted a trial also with young African American women and found that a doula program providing services such as prenatal home visits, BF support at birth, and post-partum support for 3 months with home visits and phone calls was associated with more BF attempts at the hospital as well as BF duration for more than 6 weeks but not BF duration at 4 months. Petrova et al. [67] conducted a study at a maternal and pediatric clinic in New Jersey with Hispanic women and found that prenatal education at the clinic plus additional in-hospital and postpartum BF support by phone from a lactation consultant was not associated with increases in EBF. In contrast to the previous study, Gross et al. [68] conducted a study with pregnant Hispanic women that resulted in the intervention being positively associated with EBF at 3 months (OR 1.61; 95\%CI 1.07-2.44) [68]. In this case, this intervention consisted of BF education/counseling and support delivered by a team of bilingual registered dietitians (who were also Certified Lactation Counselors) during the third trimester of pregnancy, the hospital stay, and postpartum during child well visits. Similarly, Linares et al. [69] found that a culturally tailored intervention for Hispanic women, that included prenatal education, hospital BF support with home visits, and follow-up phone counseling until 6 months postpartum delivered by a PC and supported by a lactation consultant, increased EBF. This study found that participants in the intervention group were three times more likely to EBF their baby at discharge, 1 month, 3 months, and 6 months postpartum. However, the study had a $30 \%$ attrition rate at 6 months and a small initial sample. Lastly, Chapman et al. [70] provided BF specialized peer counselling support services for low-income overweight/obese women (predominately of Hispanic origin) delivering at a $\mathrm{BFH}$, and did not find improvements in EBF or BF continuation at 1, 3, or 6 months postpartum among women who received the intervention. Nonetheless, adjusted post-hoc analyses showed that participants in the intervention group at 2 weeks postpartum had a significantly increased probability of continuing any BF (OR: 3.76 95\% CI: $1.07-13.22$ ), and offering $50 \%$ of feedings as breast milk (OR: 4.47 (95\% CI: $1.38-$ 14.5) compared with controls (who received BF PC non-specialized support).

The studies reviewed in this section suggest that interventions delivered in combination with PCs and other healthcare providers at multiple points of contact 
Table 5 Community level healthcare facility breastfeeding interventions among women of color in the U.S.: Prenatal and post-partum

\begin{tabular}{|c|c|c|c|c|c|}
\hline $\begin{array}{l}\text { Study/ } \\
\text { Setting }\end{array}$ & $\begin{array}{l}\text { Study Design/ } \\
\text { Data collection }\end{array}$ & Study Population & Intervention & Outcomes Results & Grade \\
\hline $\begin{array}{l}\text { Messito } \\
\text { et al. [60] } \\
\text { Pediatric } \\
\text { clinics }\end{array}$ & $\begin{array}{l}\text { Design: RCT } \\
\text { Data: 3rd trimester } \\
\text { baseline, chart } \\
\text { review and } 10 \text { mo } \\
\text { p.p. phone survey }\end{array}$ & $\begin{array}{l}\mathrm{N}=533 \mathrm{H}(266 \\
\text { intervention and } 267 \\
\text { controls), NY }\end{array}$ & $\begin{array}{l}1 \text { prenatal \& } 8 \text { p.p. individual } \\
\text { and group nutrition counseling; } \\
\text { delivered by bilingual RD/CLC }\end{array}$ & $\begin{array}{l}\text { Intervention group were more likely to } \\
\text { only use breastmilk as milk source for } \\
\text { their infant at } 10 \text { months p.p.; compared } \\
\text { to mothers in the control group }\end{array}$ & Moderate \\
\hline $\begin{array}{l}\text { Kao et al. } \\
\text { [61] } \\
\text { Prenatal } \\
\text { clinic }\end{array}$ & $\begin{array}{l}\text { Design: } R C T \\
\text { Data: Baseline, } \\
\text { post group } \\
\text { sessions, } 2 \text { wks p.p. } \\
\text { and } 3 \text { mo p.p. }\end{array}$ & $\begin{array}{l}N=99(53 \text { interv. and } 46 \\
\text { control); } 44.4 \% \mathrm{H}, 28 \% \mathrm{~W}, \\
14.1 \mathrm{AA} \text {; inner-city hos- } \\
\text { pital in the Northeast }\end{array}$ & $\begin{array}{l}\text { Intervention to prevent p.p. } \\
\text { depression and increase social } \\
\text { support, } 4 \text { group and } 1 \\
\text { individual p.p.session }\end{array}$ & $\begin{array}{l}\text { No between-group differences for BF } \\
\text { initiation. Intervention group BF for lon- } \\
\text { ger than controls ( } 54 \text { days vs. } 21 \text { days). } \\
\text { Intervention group twice as likely to still } \\
\text { BF at } 3 \text { mo p.p. }\end{array}$ & Very Low \\
\hline $\begin{array}{l}\text { Watt et al } \\
{[62]} \\
\text { Primary } \\
\text { Care clinic }\end{array}$ & $\begin{array}{l}\text { Design: Quasi- } \\
\text { experimental } \\
\text { prospective } \\
\text { Data: Surveys at } \\
\text { 1st and 3rd } \\
\text { pregnancy } \\
\text { trimester; } 2,6, \& 12 \\
\text { mo p.p. }\end{array}$ & $\begin{array}{l}N=61 \mathrm{H} \text { (32 interv. and } \\
20 \text { comparison group); } \\
\text { Southwest }\end{array}$ & $\begin{array}{l}\text { Nutrition and cooking group } \\
\text { classes in pregnancy and at } 1 \\
\text { and } 3 \text { mo p.p. }\end{array}$ & $\begin{array}{l}\text { At } 6 \text { mo mothers from intervention } \\
\text { group marginally more likely to BF }\end{array}$ & Low \\
\hline $\begin{array}{l}\text { Schreck } \\
\text { et al. [63] } \\
\text { Prenatal } \\
\text { clinic }\end{array}$ & $\begin{array}{l}\text { Design: Pre/post } \\
\text { quasi-experimental } \\
\text { study } \\
\text { Data: medical } \\
\text { record review, } \\
\text { phone survey at 1, } \\
3 \text { mo p.p. }\end{array}$ & $\begin{array}{l}N=330 \text { pre; } 84.5 \% A A \\
9.5 \% \mathrm{~W} \\
N=320 \text { p.p.; } 89.7 \% \mathrm{AA} \\
9.5 \% \mathrm{~W}\end{array}$ & $\begin{array}{l}10 \text { prenatal BF education } \\
\text { sessions by an IBCLCs and } 1 \text { p.p. } \\
\text { BF support group }\end{array}$ & $\begin{array}{l}\text { BF education positively associated with } \\
\text { BF initiation. Intervention mothers more } \\
\text { likely to BF and achieve prenatal BF } \\
\text { goals. }\end{array}$ & Low \\
\hline $\begin{array}{l}\text { Efrat et al. } \\
{[64]} \\
\text { Community } \\
\text { Health } \\
\text { clinics with } \\
\text { WIC } \\
\text { programs }\end{array}$ & $\begin{array}{l}\text { Design: } R C T \\
\text { Data: phone } \\
\text { surveys at } 3 \text { rd } \\
\text { trimester, } 72 \text { h p.p., } \\
1,3 \text { and } 6 \text { mo. }\end{array}$ & $\begin{array}{l}\text { Intervention } N=111 \mathrm{H} ; \\
\text { Control } N=109 \mathrm{H} ; \mathrm{LA} \\
\text { County }\end{array}$ & $\begin{array}{l}4 \text { phone calls in pregnancy and } \\
17 \text { p.p. calls from lactation } \\
\text { educator providing BF education } \\
\text { and support up to } 6 \text { mo p.p. }\end{array}$ & $\begin{array}{l}\text { No differences in BF initiation, EBF, any } \\
\text { BF at } 72 \mathrm{~h}, 1,3,6 \text { mo. }\end{array}$ & Very low \\
\hline
\end{tabular}

Abbreviations: AA African American; Al American Indian; $H$ Hispanic; $W$ White; p.p. postpartum; $R C T$ Randomized Controlled Trial; $E B F$ exclusive breastfeeding; $B F$ breastfeeding; RD Registered Dietitian; CLC Certified Lactation Counselors; IBLC International Board Certified Lactation Consultant

(prenatal, maternity hospital and postpartum), can have a positive impact on BF outcomes. Studies were of moderate $(n=2)$, low $(n=3)$ or very low $(n=1)$ quality (Table 6).

\section{Post-partum interventions}

Six randomized trials included only post-partum interventions. The first was conducted by Pugh et al. [71] with low-income African American women recruited at a birthing hospital. The intervention, consisted of a BF support team formed by a community nurse and a PC providing intensive BF support during the first 4 weeks postpartum, and continued support until 24 weeks postpartum. The intervention was positively associated with BF at 6 weeks (OR 1.71; 95\% CI 1.07, 2.76) but not 12 and 24 weeks. The second randomized study, conducted by Moon et al. [72] also with African American mothers, found that receiving information post-partum about bedsharing and risk of Sudden Infant Death Syndrome (SID) was not associated with BF or EBF rates at 2-3 weeks, 2-3 months or 5-6 months postpartum.
A third randomized study by Hopkinson et al. [73] included Hispanic immigrant women who were mix feeding in the hospital after delivery. The intervention, designed to increase EBF after discharge, found that at four weeks mothers from the intervention group were more likely to be $\mathrm{EBF}(\mathrm{OR}=1.87$; 95\% CI, 1.07-3.26). However, this change from mixed feeding to EBF was mainly due to the removal of pre-lacteals like tea or water and not a decrease in formula feeding. A fourth randomized study by Bunik et al. [74] conducted among low-income predominantly Hispanic women found that bilingual nurses providing daily telephone-based BF support (screening for lactation or medical problems) during the first 2 weeks post-partum was not associated with BF duration or exclusivity. The fifth study was a pragmatic trial conducted by Harris-Luna \& Badr [75] with Hispanic post-partum women planning to breastfeed their babies. Promotoras administered BF telephone-based support during the first 12 weeks postpartum, and results showed the probability of EBF at 12 weeks increased more than threefold (3.39; 1.01, 11.46, $p=0.04)$. However, findings from this study need to be 
Table 6 Community level healthcare facility breastfeeding interventions among women of color in the U.S.: Prenatal, in-hospital and post-partum

\begin{tabular}{|c|c|c|c|c|c|}
\hline $\begin{array}{l}\text { Study/ } \\
\text { Setting }\end{array}$ & Study Design/ methods & $\begin{array}{l}\text { Study } \\
\text { Population }\end{array}$ & Intervention & Outcomes Results & Grade \\
\hline $\begin{array}{l}\text { Wambach } \\
\text { et al. [65] } \\
\text { Prenatal } \\
\text { clinics }\end{array}$ & $\begin{array}{l}\text { Design: } \mathrm{RCT} \\
\text { Data: } 2 \text { nd trimester; } 3,6 \text { wks \& 2-6 mo } \\
\text { p.p. }\end{array}$ & $\begin{array}{l}n=128 \\
\text { intervention } \\
n=128 \\
\text { control } 1 \\
n=134 \text { usual } \\
\text { care; } \\
\text { AA } \\
\text { adolescents }\end{array}$ & $\begin{array}{l}\text { IBLC and PC provided prenatal, } \\
\text { hospital, and p.p. BF support, } \\
\text { through } 4 \text { wks p.p. }\end{array}$ & $\begin{array}{l}\text { Intervention had a positive } \\
\text { effect on BF duration but not } \\
\text { on BF initiation or EBF duration }\end{array}$ & Moderate \\
\hline $\begin{array}{l}\text { Edwards } \\
\text { et al. [66] } \\
\text { Prenatal } \\
\text { clinic }\end{array}$ & $\begin{array}{l}\text { Design: } \mathrm{RCT} \\
\text { Data: pregnancy baseline, hospital and } \\
4 \text { mo p.p. }\end{array}$ & $\begin{array}{l}\mathrm{n}=124 \\
\text { intervention } \\
n=124 \\
\text { control } \\
\text { group; AA }\end{array}$ & $\begin{array}{l}\text { Doula conducted BF prenatal } \\
\text { home visits, birth, } 3 \text { mo p.p. }\end{array}$ & $\begin{array}{l}\text { Doula services increased in- } \\
\text { hospital BF attempts and BF }>6 \\
\text { weeks but not at } 4 \text { months } \\
\text { among young AA }\end{array}$ & Low \\
\hline $\begin{array}{l}\text { Petrova } \\
\text { et al. [67] } \\
\text { Health } \\
\text { Center }\end{array}$ & $\begin{array}{l}\text { Design: } \mathrm{RCT} \\
\text { Data: } 3 \text { rd trimester, } 7 \text { days, 1,2,3 mo p.p. }\end{array}$ & $\begin{array}{l}\mathrm{n}=52 \\
\text { intervention } \\
n=52 \\
\text { control; } 87.5 \% \\
\text { H; New } \\
\text { Brunswick, NJ }\end{array}$ & $\begin{array}{l}\text { Prenatal BF classes, in hospital } \\
\text { and p.p. BF support from IBLC } \\
\text { by phone }\end{array}$ & $\begin{array}{l}\text { No differences in BF initiation or } \\
\text { EBF at } 7 \text { d., 1,2,3, mo p.p. }\end{array}$ & Low \\
\hline $\begin{array}{l}\text { Gross et al } \\
{[68]} \\
\text { Primary } \\
\text { care } \\
\text { Prenatal/ } \\
\text { Pediatric } \\
\text { Clinic }\end{array}$ & $\begin{array}{l}\text { Design: } \mathrm{RCT} \\
\text { Data: } 3 \text { rd trimester, chart review, } 3 \text { mo } \\
\text { p.p.; phone survey }\end{array}$ & $\begin{array}{l}\mathrm{n}=266 \\
\text { intervention } \\
n=266 \\
\text { control; } \\
100 \% \mathrm{H}\end{array}$ & $\begin{array}{l}\text { RD/LC delivered prenatal } \\
\text { education and provided p.p. BF } \\
\text { counseling }\end{array}$ & $\begin{array}{l}\text { Intervention increase EBF } \\
\text { prevalence and BF intensity } \\
\text { after discharge but not during } \\
\text { the hospital stay. }\end{array}$ & Moderate \\
\hline $\begin{array}{l}\text { Linares } \\
\text { et al. [69] } \\
\text { Primary } \\
\text { Health } \\
\text { Care clinic }\end{array}$ & $\begin{array}{l}\text { Design: } \mathrm{RCT} \\
\text { Data: } 2 \text { prenatal surveys, chart review; } 1 \text {, } \\
3 \text { mo p.p. survey }\end{array}$ & $\begin{array}{l}n=20 \\
\text { intervention } \\
n=19 \\
\text { control; } 100 \% \\
\mathrm{H}\end{array}$ & $\begin{array}{l}\text { BF prenatal education by IBLC \& } \\
\text { PC with home visits, BF support } \\
\text { at Hospital,1st and 2nd wk. p.p. }\end{array}$ & $\begin{array}{l}\text { Intervention increased EBF at all } \\
\text { points. No differences in BF } \\
\text { initiation. }\end{array}$ & Very low \\
\hline $\begin{array}{l}\text { Chapman } \\
\text { et al. [70] } \\
\text { Prenatal } \\
\text { Clinic }\end{array}$ & $\begin{array}{l}\text { Design: RCT } \\
\text { Data: baseline survey, 3rd trimester } \\
\text { phone survey, chart review, } 24 \text { h, survey } \\
\text { at } 2 \text { wks and monthly thereafter until } 6 \\
\text { mo p.p. }\end{array}$ & $\begin{array}{l}n=76 \\
\text { intervention; } \\
80 \% \mathrm{H} \\
\text { women } \\
n=79 \\
\text { Control; } \\
83.3 \% \mathrm{H} ; \\
\text { Overweight } \\
\text { women; } \\
\text { Hartford, CT }\end{array}$ & $\begin{array}{l}\text { IBCL \& PC prenatal BF education, } \\
\text { in-hospital BF support, } 11 \text { p.p. PC } \\
\text { home visits; supported BF } \\
\text { among obese. }\end{array}$ & $\begin{array}{l}\text { Intervention impacted any BF } \\
\text { and BF intensity at } 2 \text { weeks p.p. } \\
\text { but not with EBF } \\
\text { Intervention infants less likely to } \\
\text { be hospitalized after discharge }\end{array}$ & Low \\
\hline
\end{tabular}

Abbreviations: AA African American; Al American Indian; $H$ Hispanic; W White; p.p. postpartum; RCT Randomized Controlled Trial; RD Registered Dietician; $L C$ Lactation counselor; IBCLC International Board Certified Lactation Consultant; PC peer counselor; EBF exclusive breastfeeding; $B F$ breastfeeding

interpreted with caution since randomization procedures were not adequate as participants were assigned to intervention or control group sequentially based on their appointment time. The sixth randomized study was conducted by Howell et al. [76] with Hispanic and Black mothers receiving a behavioral intervention preparing them for the post-partum period by providing education about BF management, the importance of social support, and self-care during this sensitive period of time. The intervention had a positive impact on BF duration (median BF duration: 12.0 weeks in intervention vs. 6.5 weeks in control; $p=0.02$ ).

Two retrospective studies yielded important findings. An observational retrospective study by Bream et al. [77] conducted with predominantly African American women found no association between reported use or request of a breast pump at infant's first newborn visit (14 days postpartum) and EBF at 1.5-3.5 months. However, breast pumps were associated with increased use of expressed breast milk and decreased feeding at the breast. Thus, using breast pumps was associated with lower rates of any BF at 1.5-3.5 months. In a retrospective multi race/ethnicity study, Mercier et al. [78] documented that Medicaid-insured mothers were significantly less likely to EBF or provide any $\mathrm{BF}$ at 6 to 8 weeks postpartum compared with commercially insured mothers.

The studies reviewed in this section suggest on the one hand that $\mathrm{BF}$ interventions delivered during the 
Table 7 Community level healthcare facility breastfeeding interventions among women of color in the U.S.: Post-partum

\begin{tabular}{|c|c|c|c|c|c|}
\hline $\begin{array}{l}\text { Study/ } \\
\text { Setting }\end{array}$ & $\begin{array}{l}\text { Study Design/ } \\
\text { methods }\end{array}$ & $\begin{array}{l}\text { Study } \\
\text { Population }\end{array}$ & Exposure/Intervention & Outcomes Results & Grade \\
\hline $\begin{array}{l}\text { Pugh et al. } \\
{[71]} \\
\text { Urban } \\
\text { hospitals }\end{array}$ & $\begin{array}{l}\text { Design: } \mathrm{RCT} \\
\text { Data: baseline, 6, 12, } \\
24 \text { wks p.p. phone/ } \\
\text { home survey }\end{array}$ & $\begin{array}{l}n=168 \\
\text { intervention } \\
n=160 \\
\text { control } \\
87 \% \text { AA }\end{array}$ & $\begin{array}{l}\text { Three 1-4th wks p.p. PC home visits; PC } \\
\text { bi-weekly phone calls, nurse available 24/ } \\
7 \text { by pager first } 24 \text { wks p.p. }\end{array}$ & $\begin{array}{l}\text { At } 6 \text { wks p.p., intervention mothers } 1.71 \\
\text { times more likely to BF. No significant } \\
\text { \%BF differences at } 12 \text { and } 24 \text { wks p.p. }\end{array}$ & Low \\
\hline $\begin{array}{l}\text { Moon et al. } \\
{[72]} \\
\text { Urban } \\
\text { Hospital }\end{array}$ & $\begin{array}{l}\text { Design: } \mathrm{RCT} \\
\text { Data: surveys; } 1-2 \mathrm{~d} \\
\text { p.p., } 2 \text { wks, } 2-3 \mathrm{mo} \text {, } \\
\text { 5-6 mo p.p. }\end{array}$ & $\begin{array}{l}n=569 \\
\text { intervention } \\
n=625 \\
\text { control } \\
100 \% \text { AA }\end{array}$ & $\begin{array}{l}\text { Information on AAP safe sleep practices } \\
\text { to reduce SIDS risk }\end{array}$ & $\begin{array}{l}\text { No impact on BF or EBF rates despite } \\
\text { emphasis on not bedsharing. }\end{array}$ & Very Low \\
\hline $\begin{array}{l}\text { Hopkinson } \\
\text { et al. [73] } \\
\text { Community } \\
\text { clinic }\end{array}$ & $\begin{array}{l}\text { Design: } \mathrm{RCT} \\
\text { Data: Chart review, } \\
\text { baseline survey, } \\
\text { phone at } 4 \text { wks p.p. }\end{array}$ & $\begin{array}{l}n=255 \\
\text { intervention } \\
n=267 \\
\text { control. } \\
87.5 \% \mathrm{H}\end{array}$ & $\begin{array}{l}\text { Moms mix feeding scheduled for a } 3-7 \\
\text { p.p. visit to clinic; PC \& IBCLC BF support; }\end{array}$ & $\begin{array}{l}\text { Intervention increased EBF at } 4 \text { wks, } \\
\text { mostly due to less water and herbal teas } \\
\text { (vs. formula) }\end{array}$ & Moderate \\
\hline $\begin{array}{l}\text { Bunik et al. } \\
{[74]} \\
\text { Community } \\
\text { health } \\
\text { center }\end{array}$ & $\begin{array}{l}\text { Design: } R C T \\
\text { Data: Hospital, 1,3,6 } \\
\text { mo p.p. phone } \\
\text { survey }\end{array}$ & $\begin{array}{l}n=161 ; 87 \% \\
H \\
n=180 ; 90 \% \\
H\end{array}$ & $\begin{array}{l}\text { daily BF support phone calls; bilingual } \\
\text { nurses; } 1 \text { st } 2 \text { wks p.p. }\end{array}$ & $\begin{array}{l}\text { No differences in any or predominantly } \\
\text { BF at } 1,3,6 \text { mo p.p. }\end{array}$ & Very Low \\
\hline $\begin{array}{l}\text { Harris-Luna } \\
\& \\
\text { Badr [75] } \\
\text { Obstetric } \\
\text { clinics }\end{array}$ & $\begin{array}{l}\text { Design: Pragmatic } \\
\text { RCT } \\
\text { Data: in-person } \\
\text { baseline survey; } 12 \\
\text { wks phone survey }\end{array}$ & $\begin{array}{l}n=31 \\
\text { intervention } \\
n=30 \\
\text { control; } 100 \% \\
\mathrm{H} \text {; Southern } \\
\text { CA }\end{array}$ & $\begin{array}{l}\text { Promotoras BF phone daily support } 4 \\
\text { wks p.p., then biweekly until } 12 \text { wks p.p. }\end{array}$ & $\begin{array}{l}\text { Increased EBF at } 12 \text { wks p.p.; longer BF } \\
\text { duration }\end{array}$ & Very Low \\
\hline $\begin{array}{l}\text { Howell et al. } \\
\text { [76] } \\
\text { Tertiary } \\
\text { hospital }\end{array}$ & $\begin{array}{l}\text { Design: } \mathrm{RCT} \\
\text { Data: Baseline, } 3 \\
\text { wks, 3, } 6 \text { mo p.p. }\end{array}$ & $\begin{array}{l}\mathrm{n}=270 \\
\text { intervention } \\
64 \% \mathrm{H} ; 36 \% \\
\mathrm{AA} \\
n=270 \\
\text { Control } \\
61 \% \mathrm{H} ; 39 \% \\
\mathrm{AA} ; \mathrm{NY}\end{array}$ & $\begin{array}{l}\text { p.p. behavioral education; BF tips, social } \\
\text { support/self-management skills. }\end{array}$ & $\begin{array}{l}\text { Longer BF duration; less likely to stop BF } \\
\text { during first } 6 \text { mo p.p. }\end{array}$ & Moderate \\
\hline $\begin{array}{l}\text { Bream et al. } \\
{[77]} \\
\text { Pediatric } \\
\text { clinic }\end{array}$ & $\begin{array}{l}\text { Design: } \\
\text { Retrospective } \\
\text { Data: chart review } \\
\text { first } 14 \text { d p.p., } 2 \text { mo } \\
\text { p.p. survey }\end{array}$ & $\begin{array}{l}N=355 ; 96 \% \\
\mathrm{AA} ; \text { Cleveland } \\
\mathrm{OH}\end{array}$ & $\begin{array}{l}\text { BF mothers requesting } \\
\text { a breast pump or using one at } 14 \text { days } \\
\text { p.p. }\end{array}$ & $\begin{array}{l}\text { Breast-pumps did not increase EBF at } 2 \\
\text { mo; less BF at } 2 \text { mo p.p. }\end{array}$ & Very Low \\
\hline $\begin{array}{l}\text { Mercier } \\
\text { et al. [78] } \\
\text { University } \\
\text { Hospital }\end{array}$ & $\begin{array}{l}\text { Design: } \\
\text { Observational } \\
\text { Retrospective study } \\
\text { Data: chart review; } \\
\text { hospital \& 6-8 wks } \\
\text { p.p. }\end{array}$ & $\begin{array}{l}\mathrm{N}=405 ; 54 \% \\
\mathrm{AA} ; 11 \% \mathrm{As} ; \\
11 \% \mathrm{H} ; \\
\text { Philadelphia }\end{array}$ & $\begin{array}{l}\text { Exposure: Insurance status; Medicaid or } \\
\text { commercial insurance }\end{array}$ & $\begin{array}{l}\text { Among } A A \text {, no significant differences in } \\
\text { BF rates AA with or without commercial } \\
\text { insurance. }\end{array}$ & Low \\
\hline
\end{tabular}

Abbreviations: A Asian; AA African American; Al American Indian; $H$ Hispanic; W White; p.p. postpartum; $P C$ peer counselor; $R C T$ Randomized Controlled Trial. IBCL International Board Certified Lactation Consultant; $P C$ peer counselor; EBF exclusive breastfeeding; $B F$ breastfeeding; SIDS Sudden Infant Death Syndrome

postpartum period have mixed results. On the other hand, $\mathrm{BF}$ interventions delivered during the perinatal period that may have some positive effect on $B F$ outcomes. Breast pumps may not increase BF but rather increase the proportion of feeds involving expressed breast milk. Studies were of moderate $(n=2)$, low $(n=2)$ or very low $(n=3)$ quality (Table 7$)$. Furthermore, the study by Howell, et al. [76], illustrates the importance of including appropriated behavior change frameworks when designing and evaluating BF interventions targeting minority women [79].
The Special Supplemental Nutrition Program for Women, Infants, and Children (WIC) interventions

Marshall et al. [80] conducted a cross-sectional analysis of Mississippi's 2004-2008 PRAMS data and found that WIC participation was negatively associated with BF initiation among non-Hispanic White women (OR 0.87; 95\% CI 0.77-0.99), but not among Black women (OR $0.99 ; 0.28-1.21$ ) [80]. In a retrospective observational study using Maryland's 2007 WIC program administrative data $(n=33,582)$, Gross et al. [81] found that, at the time of postpartum WIC certification, meaning that the 
mother and child met the program's eligibility lowincome and other criteria to receive program benefits according to the status of the mother (pregnant versus postpartum) and infant feeding choices made by the mother; i.e. full BF, partial BF, formula feeding [82]. Hispanic infants were more likely to be certified as partially BF (49\%) when compared with non-Hispanic White (11\%) and African American infants (20.5\%; $p<0.001)$. They were also more likely to be certified after 2 weeks of age (46.1\%) when compared with non-Hispanic White infants (31.6\%) and African American infants (28.6\%; $\mathrm{p}<0.001)$. At the time of certification, BF initiation rate was higher among women receiving peer counseling compared with those receiving a lactation consultant or standard of care services $(61.6 \%$ vs. 54.4 and $47.6 \%$, respectively; $\mathrm{p}<0.001)$. In this study, peer counseling was also positively associated with being certified as exclusively and partially BF compared with the lactation consultants and standard of care groups $(36.0 \%$ vs. 24.8 and $25.3 \%$, respectively; $\mathrm{p}<0.001$ ).

There were four studies conducted among WIC participants where the intervention was compared with a group already receiving some WIC BF support services. The first one, conducted in Philadelphia by Washio et al. [83] with Puerto Rican mothers, provided monthly cash incentives to $\mathrm{BF}$ mothers to incentivize continuation. The incentives led to increased $\mathrm{BF}$ duration at 1 month ( $89 \%$ vs. $44 \%, P=0.01)$; 3 months $(89 \%$ vs. $17 \%, P<$ $0.001)$; and 6 months $(72 \%$ vs. $0 \%, \mathrm{P}<0.001)$ postpartum. However, the intervention had no impact on EBF, possibly due to the low sample size for this analysis. The second and third studies focused on the same two-way text messaging BF counseling intervention, LATCH (Lactation Advice Through Texting Can Help). The LATCH pilot RCT, conducted by Harari et al. [84], was followed by a larger scale RCT conducted by Martinez-Brockman et al. [85]. Both studies were conducted in Connecticut through WIC clinics and one community agency. LATCH delivered automated and personalized BF behavior change text messages from pregnancy to post-partum period as a tool to enhance BF PC services. Both studies confirmed the feasibility of LATCH and underlined how helpful the intervention was for establishing contact with women significantly sooner after birth. Yet, no significant effect of this intervention was seen on EBF or any BF at 2 or 3 months postpartum. The fourth study was a quasi-experimental study conducted by Lovera et al. [86] in Texas. Fathers of breastfed infants were hired as peer dads to provide BF information and support to other fathers with breastfed infants participating in WIC and receiving BF peer counseling services. The peer dad program was not associated with BF duration.

Three additional studies assessed different modalities to deliver or enhance WIC BF support services $[87,88]$. In a randomized study in Oregon at 4. WIC offices (2 rural and 2 urban sites), Reeder et al. [87] assessed the impact of a telephone-based peer counselling service on BF outcomes as an alternative model to the more expensive in-person peer counselling model. Findings revealed that telephone calls from $\mathrm{PC}$ were associated with higher $\mathrm{BF}$ duration at 3 months postpartum (AOR 1.22; 95\% CI: 1.10-1.34). However, at 6 months, this relationship was only found among Spanish-speaking clients (1.29; CI: 1.10-1.51). Edmunds et al. [88] conducted a quasi-experimental study where pregnant women intending to breastfeed their babies were recruited from 12 WIC clinics to participate in the You Can Do It intervention. In the intervention, women received a tailored individual plan with BF counseling from pregnancy through the immediate postpartum period. The intervention was positively associated with EBF at 7 days (OR 1.6; 85\% CI 1.1-2.5) and 30 days postpartum (1.6; 1.0-2.5), but not at 60 days. When examined by race/ethnicity, the positive impacts on $\mathrm{EBF}$ rates were documented among Black and Hispanic at 30 and 60 days postpartum but not non-Hispanic White women. Another simple quasi-experimental intervention examined the effect of a bilingual video used at a WIC office in NY City that encouraged mothers to $\mathrm{BF}$, however no impact on $\mathrm{BF}$ outcomes was seen [89].

The studies reviewed in this section suggest that, even though the WIC population is at high risk of poor BF outcomes, there is still a dearth of consistent evidence on effective BF interventions that can be delivered through WIC clinics. Overall, postpartum interventions delivered by PCs have a positive impact on BF outcomes. In this section we identified interventions designed to complement WIC BF support services already offered at WIC offices that included financial incentives and behavior change based text messaging. The latter interventions seem promising but it is important to continue exploring the use of information technologies, including telehealth, to strengthen the reach and depth of peer counseling and other BF support services at WIC. Studies were of moderate $(n=$ $1)$, low $(n=5)$ or very low $(n=3)$ quality (Table 8$)$.

\section{Community agency interventions}

Four community intervention studies were randomized controlled trials. The first study was conducted by Cloutier et al. [90] in Hartford, CT with a predominantly Hispanic population receiving enhanced services with a BF component from the Nurturing Family Network (NFN). Despite the small sample and high attrition rate (28\%) (half in the control group were lost to follow-up 
Table 8 Community level Supplemental Nutrition Program for Women, Infants, and Children (WIC) breastfeeding interventions among women of color in the U.S.

\begin{tabular}{|c|c|c|c|c|c|}
\hline $\begin{array}{l}\text { Study/ } \\
\text { Setting }\end{array}$ & $\begin{array}{l}\text { Study Design/ } \\
\text { methods }\end{array}$ & Study Population & Exposure/Intervention & Outcomes/Results & Grade \\
\hline $\begin{array}{l}\text { Marshall } \\
\text { et al. [80] } \\
\text { PRAMS data }\end{array}$ & $\begin{array}{l}\text { Design: } \\
\text { Retrospective } \\
\text { Data:2004,2006, } \\
2008 \\
\text { Mississippi } \\
\text { PRAMS }\end{array}$ & $\begin{array}{l}N=1739 \text { W; } 52.2 \% \\
N=1975 \text { AA; } 82 \% \text { enrolled in } \\
\text { WIC Mississippi }\end{array}$ & $\begin{array}{l}\text { WIC vs. eligible non-WIC } \\
\text { participants }\end{array}$ & $\begin{array}{l}\text { WIC participation not associated with BF } \\
\text { initiation among A }\end{array}$ & Low \\
\hline $\begin{array}{l}\text { Gross et al. } \\
{[81]} \\
\text { WIC }\end{array}$ & $\begin{array}{l}\text { Design: } \\
\text { Retrospective } \\
\text { Data: WIC }\end{array}$ & $\begin{array}{l}\mathrm{N}=33,582 ; 50.5 \% \mathrm{AA} ; 23.8 \% \mathrm{H} ; \\
22.1 \% \mathrm{~W} ; \text { Maryland }\end{array}$ & $\begin{array}{l}\text { BF support by PC, IBLC vs. } \\
\text { standard of care (SC) }\end{array}$ & $\begin{array}{l}\text { BF initiation rate higher for PC vs. IBLC and } \\
\text { SC groups. }\end{array}$ & Very Low \\
\hline $\begin{array}{l}\text { Washio et al. } \\
{[83]} \\
\text { WIC clinic }\end{array}$ & $\begin{array}{l}\text { Design: } R C T \\
\text { Data: Baseline, } \\
\text { 1,3,6 mo }\end{array}$ & $\begin{array}{l}\mathrm{n}=18 \text { intervention; } n=18 \\
\text { control, } 100 \% \text { Puerto Rican; } \\
\text { Philadelphia }\end{array}$ & $\begin{array}{l}\text { WIC BF support services } \\
\text { plus incremental financial } \\
\text { incentives per month BF }\end{array}$ & Higher BF at 1, 3, and 6 mo vs. controls & Low \\
\hline $\begin{array}{l}\text { Harari et al. } \\
\text { [84] } \\
\text { WIC clinics }\end{array}$ & $\begin{array}{l}\text { Design: pilot } \\
\text { RCT } \\
\text { Data: baseline } \\
\text { intake; } 2 \text { wks } \\
\text { p.p. phone } \\
\text { survey }\end{array}$ & $\begin{array}{l}\mathrm{n}=32 \text { intervention; } \mathrm{n}=26 \\
\text { control; } 75 \% \mathrm{H} ; 17 \% \mathrm{AA} ; 6 \% \mathrm{~W} ; \\
\text { New Haven } \mathrm{CT}\end{array}$ & $\begin{array}{l}\text { Personalized text } \\
\text { messages + BF PC services } \\
\text { during pregnancy and p.p. }\end{array}$ & $\begin{array}{l}\text { EBF at } 2 \text { weeks higher in intervention (NS). } \\
\text { Intervention mothers were contacted } \\
\text { sooner and more likely to meet BF goals }\end{array}$ & Moderate \\
\hline $\begin{array}{l}\text { Martinez- } \\
\text { Brockman } \\
\text { et al. [85] } \\
\text { WIC clinics }\end{array}$ & $\begin{array}{l}\text { Design: } \mathrm{RCT} \\
\text { Data: baseline, } 2 \\
\text { wks, } 3 \text { mo p.p. } \\
\text { phone surveys }\end{array}$ & $\begin{array}{l}N=94 \text { intervention } \\
n=80 \text { control } \\
74.3 \mathrm{H} \% ; C T\end{array}$ & $\begin{array}{l}\text { PC services + two-way } \\
\text { text messages from preg- } \\
\text { nancy to } 3 \text { mo p.p. }\end{array}$ & $\begin{array}{l}\text { EBF rates at } 2 \text { wks p.p. higher (NS). } \\
\text { Intervention moms contacted sooner. NS } \\
\text { between-group differences in EBF at } 3 \text { mo }\end{array}$ & Low \\
\hline $\begin{array}{l}\text { Lovera et al. } \\
\text { [86] } \\
\text { WIC clinic }\end{array}$ & $\begin{array}{l}\text { Design: Quasi } \\
\text { experimental } \\
\text { Data: WIC } \\
\text { records }\end{array}$ & $\begin{array}{l}\mathrm{n}=53 \text { intervention; } 100 \% \mathrm{H} ; \\
\mathrm{n}=49 \text { control } 100 \% \mathrm{H} ; \\
\text { Brownsville TX }\end{array}$ & $\begin{array}{l}\mathrm{PC}+\text { peer dad counseling } \\
\text { services }\end{array}$ & $\begin{array}{l}\text { NS between-group difference in BF } \\
\text { duration }\end{array}$ & Very low \\
\hline $\begin{array}{l}\text { Reeder et al. } \\
{[87]} \\
\text { WIC clinics }\end{array}$ & $\begin{array}{l}\text { Design: } \mathrm{RCT} \\
\text { Data: } 1 \text { st } \\
\text { trimester, } 7,30, \\
60 \text { days p.p. }\end{array}$ & $\begin{array}{l}n=645 \text { PC high freq. } \\
n=646 \text { PC low freq. } \\
n=657 \text { control; } 100 \% \text { H; } 4 \\
\text { clinics; Oregon }\end{array}$ & $\begin{array}{l}\text { Low freq. PC group: } 4 \\
\text { calls; High freq. PC group: } \\
8 \text { phone calls }\end{array}$ & $\begin{array}{l}\text { Intervention increased EBF and any BF } \\
\text { duration among Spanish speaking WIC } \\
\text { participants. NS among English speaking. }\end{array}$ & Low \\
\hline $\begin{array}{l}\text { Edmunds } \\
\text { et al. [88] } \\
\text { WIC clinics }\end{array}$ & $\begin{array}{l}\text { Design: Quasi- } \\
\text { experimental. } \\
\text { Data: 1st } \\
\text { trimester, 7,30, } \\
60 \text { days p.p. }\end{array}$ & $\begin{array}{l}n=362 \text { intervention; } n=408 \\
\text { control; } 11.1 \% \text { W, } 30.7 \% \text { AA, } \\
51.2 \% \text { H, } 12 \text { clinics; NY State }\end{array}$ & $\begin{array}{l}\text { Individual counseling } \\
\text { tailoring }\end{array}$ & $\begin{array}{l}\text { Intervention increased EBF among } \mathrm{H} \text { and } \\
\mathrm{AA} \text { at } 30 \& 60 \text { days p.p. }\end{array}$ & Low \\
\hline $\begin{array}{l}\text { Scheinmann } \\
\text { et al. [89] } \\
\text { WIC clinics }\end{array}$ & $\begin{array}{l}\text { Design: Quasi- } \\
\text { experimental. } \\
\text { Data: baseline, } \\
\text { 3, } 6 \text { mo p.p. }\end{array}$ & $N=439 ; 100 \% \mathrm{H}$ & $\begin{array}{l}\text { 25-min English/Spanish } \\
\text { educational BF video }\end{array}$ & $\begin{array}{l}\text { NS differences in any BF between video } \\
\text { and comparison groups at baseline, } 3 \& 6 \\
\text { mo }\end{array}$ & Very low \\
\hline
\end{tabular}

Abbreviations: AA African American; $H$ Hispanic; W White; NS not significant; p.p. postpartum; $P C$ peer counselor; $R C T$ Randomized Controlled Trial

at 6 months), the intervention increased $\mathrm{BF}$ at 6 and 12 months (but not BF initiation) compared to those mothers not receiving the intervention. The second randomized study, conducted by Sandy et al. [91] in New York among low-income Hispanic immigrant women, showed that a BF education and support intervention offered during pregnancy and postpartum through a home visiting maternal program had a positive impact on EBF during the first week post-partum but did not have a significant impact on BF duration. However, EBF was measured based on only breastmilk with no formula without assessing pre-lacteal feedings. The third randomized study was conducted by Lutenbacher et al. [92] among Hispanic women and assessed the impact of a home visiting program utilizing peer educators from pregnancy through 6 months. The study found that the intervention group had a longer duration of EBF compared to the control group (1.4 vs 0.3 weeks, respectively). The fourth randomized study, conducted by Hans et al. [93] in Illinois, found a positive impact of a doula home visiting program on BF initiation ( $81 \%$ vs. $74 \%$; $\mathrm{OR}=1.67,0.91-$ $3.03, p=.05)$, but not on BF rates at 3 months $(16.9 \%$ vs. $21.8 \%$; OR $=0.85,0.45-1.60$ ) .

Four community intervention studies were quasiexperimental studies. Karanja et al. [94] designed an intervention to limit sugary drink intake and improve BF practices among AI/AN toddlers. Findings showed that a social media campaign combined with a home-based community health worker $(\mathrm{CHW})$ intervention was associated with higher $\mathrm{BF}$ initiation and $\mathrm{BF}$ duration rates at 
6 months when compared to national data for the AI/ AN populations. Thomson et al. [95] tested an early childhood obesity prevention intervention focused on gestational weight gain, BF, mother and infant nutrition, and physical activity with clients of the Parents as Teachers (PAT) home visiting program, who were high school and college educated African American women living in several Mississippi counties. The intervention did not significantly impact any BF outcomes. In the Moms First Project with African American women, Furman et al. [96] tested a pregnancy and postpartum intervention that included doula services and a lactation counselor providing BF support through home visits and phone calls. Among intervention participants, any BF was associated with a higher receipt of curricular modules and number of post-partum home visit, while EBF was only associated with a higher number of postpartum home visits. Results from this study only included women receiving an intervention since there were incomplete BF outcome data from control participants. Lastly, Lewkowitz et al. [97] tested a prenatal home-based lifestyle intervention by parents to overweight/obese African American pregnant women using an enhanced (i.e. included a BF component) Parent as Teacher Curriculum. The intervention did not impact $\mathrm{BF}$ initiation rates.

Three community interventions were observational studies. First, a study conducted by Leruth et al. [98] among African American women, found that a Healthy Start Program (HSP) in Chicago, Illinois that incorporated BF education and support by certified lactation counselors (CLC) from pregnancy through 6 months postpartum had a positive impact on $\mathrm{BF}$ initiation. However, results must be interpreted with caution since the program lacked baseline BF data before the incorporation of $\mathrm{BF}$ supportive services. Instead, BF initiation rates from the study were compared to one partner hospital receiving the program services the year before the implementation of BF support services to the HSP. Second, in a study conducted with a diverse group of Medicaid recipient women who received doula services during the perinatal period, Kozhimannil et al. [99] reported a high BF initiation rate (97.9\%) among those receiving this service when compared with state based data of Medicaid recipient women not receiving this service (80.8\%). Furthermore, doula services had a significant impact on BF initiation rates among African American women which were $92.7 \%$ compared with $70.3 \%$ of the general Medicaid population not receiving the services. Lastly, a comparative observational study assessing the efficacy of implementing a perinatal home visiting program using mother-to-mother support (regarding BF and other postpartum topics) during the perinatal period did not impact BF outcomes [100].

Collectively, the studies reviewed in this section strongly suggest that community-based interventions delivered through community agencies and that include home visits can have a positive impact on BF outcomes among minority women. Almost all studies focused on African American or Hispanic women. Studies were of moderate $(n=1)$, low $(n=3)$ or very low $(n=3)$ quality (Table 9).

\section{Interpersonal level}

Three studies (two cross-sectional and one experimental) were at the interpersonal level. First, in a cross-sectional study conducted with low-income, predominantly African American women, Ashida et al. [101] found that mothers that received more supportive rather than undermining $\mathrm{BF}$ advice were 1.8 times more likely to ever breast-feed $(\mathrm{OR}=1.8 ; 95 \%$ CI $1.1-$ 3.0). Furthermore, the presence of supportive BF information was significantly associated with a higher likelihood of ever BF $(2.0 ; 1.0-3.8)$ [101]. Another cross-sectional study conducted by Thomas et al. [102] that interviewed women at a pediatric clinic found that mothers with an accompanying person were more likely to be exclusively BF when compared with those women without an accompanying adult ( $47 \%$ vs. $33 \%$, respectively; $p=0.04$ ). Finally, an experimental study conducted by Wilhelm et al. [103] did not find motivational interviewing to be effective at increasing self-efficacy and BF at 6 months among Mexican women living in rural areas. However, this study had a high attrition rate and small sample size [103].

These studies suggest that interpersonal support may improve BF outcomes among minority women and there is a need to conduct more research in this area. Studies were low $(n=1)$ or very low $(n=2)$ quality (Table 10$)$.

\section{Discussion}

Over the past decade, BF rates have increased among all racial/ethnic groups in the U.S. but inequities still exist. Ethnic/racial minority women breastfeed exclusively for shorter periods of time [25] and are significantly less likely to meet their BF goals compared to non-Hispanic White women [104]. Our systematic review (SR) sheds some light as to why this may be the case following a socioecological framework.

\section{Policy level}

Half of the 6 included articles included at the federal and state policy level assessed the impact of BF supporting laws on BF outcomes. Findings demonstrated that laws at the federal level influenced ever BF with the 
Table 9 Community level community agencies breastfeeding interventions among women of color in the U.S.

\begin{tabular}{|c|c|c|c|c|c|}
\hline Study & Study Design & Study Population & Intervention & Outcomes & Grade \\
\hline $\begin{array}{l}\text { Cloutier, } \\
\text { et al. [90] } \\
\text { Home } \\
\text { visiting } \\
\text { program }\end{array}$ & $\begin{array}{l}\text { Design: } \mathrm{RCT} \\
\text { Data: baseline, } 6, \\
12 \text { mo p.p. survey }\end{array}$ & $\begin{array}{l}n=30 \text { intervention: } 24 \% \text { AA; } \\
52 \% \text { H; } 24 \% \text { Other; } n=27 \\
\text { control: } 24 \% \text { AA; } 52 \% \text { H;24\%; } 6 \\
\text { sites; Hartford CT }\end{array}$ & $\begin{array}{l}\text { Standard NFN curricula plus } \\
\text { enhanced BF/Responsive parenting } \\
\text { modules. }\end{array}$ & $\begin{array}{l}\text { No impact on BF initiation; } \\
\text { positive impact on BF at } 6 \\
\text { and } 12 \text { mo }\end{array}$ & Very low \\
\hline $\begin{array}{l}\text { Sandy, et al. } \\
\text { [91] } \\
\text { Home } \\
\text { visiting } \\
\text { program }\end{array}$ & $\begin{array}{l}\text { Design: RCT } \\
\text { Data: baseline, } 1 \\
\text { wk. p.p. }\end{array}$ & $\begin{array}{l}n=137 \text { intervention, } n=101 \\
\text { control; all H mostly Dominican; } \\
\text { NY City }\end{array}$ & $\begin{array}{l}\text { Prenatal home visits by FSWs; SC } \\
\text { curricula + BF education + BF } \\
\text { support, pediatric resident visit } 1 \text { wk. } \\
\text { p.p. }\end{array}$ & $\begin{array}{l}\text { EBF but not any BF } \\
\text { associated with } \\
\text { intervention at } 1 \text { st week } \\
\text { p.p. }\end{array}$ & Very Low \\
\hline $\begin{array}{l}\text { Lutenbacher } \\
\text { et al. [92] } \\
\text { Home } \\
\text { visiting } \\
\text { program }\end{array}$ & $\begin{array}{l}\text { Design: } R C T \\
\text { Data: baseline, } 2 \\
\text { wk., } 2 \text { \& } 6 \text { mo p.p. }\end{array}$ & $\begin{array}{l}\mathrm{n}=94 \text { Intervention; } n=94 \\
\text { controls; all H; Tennessee }\end{array}$ & $\begin{array}{l}\text { Maternal Infant Health home visiting } \\
\text { Program vs. only written information }\end{array}$ & $\begin{array}{l}\text { Intervention improved EBF } \\
\text { duration }\end{array}$ & Moderate \\
\hline $\begin{array}{l}\text { Hans et al. } \\
\text { [93] } \\
\text { Community } \\
\text { agencies }\end{array}$ & $\begin{array}{l}\text { Design: } \mathrm{RCT} \\
\text { Data: } 3 \text { rd } \\
\text { pregnancy } \\
\text { trimester, } 3 \text { wks \& } \\
3 \text { mo p.p. }\end{array}$ & $\begin{array}{l}N=129 \text { Intervention: } 43.6 \% \mathrm{AA} \\
39.1 \% \mathrm{H}, 8.3 \% \mathrm{~W} ; \mathrm{n}=27 \text { control: } \\
46.2 \% \mathrm{AA}, 35.9 \% \mathrm{H}, 8.3 \% \mathrm{~W} ; n= \\
4 \text { agencies }\end{array}$ & $\begin{array}{l}\text { Home visitor + doula; pregnancy and } \\
\text { up to } 6 \text { wks p.p. }\end{array}$ & $\begin{array}{l}\text { Intervention improved BF } \\
\text { initiation; no impact on BF } \\
\text { at } 3 \text { months p.p. }\end{array}$ & Low \\
\hline $\begin{array}{l}\text { Karanja et al. } \\
{[94]} \\
\text { Home } \\
\text { visiting } \\
\text { program }\end{array}$ & $\begin{array}{l}\text { Design: Quasi-exp. } \\
\text { Data: national } \\
\text { data }, 6 \text { mo survey, } \\
\text { visit logs, WIC } \\
\text { records }\end{array}$ & $\begin{array}{l}N=142 \text { mother and child } \\
\text { All Al/AN; Oregon }\end{array}$ & $\begin{array}{l}8 \text { CHWs home visits; pregnancy thru } \\
\text { child second y }\end{array}$ & $\begin{array}{l}\text { BF initiation and } 6 \text {-mo rates } \\
\text { higher than national } \\
\text { average }\end{array}$ & Low \\
\hline $\begin{array}{l}\text { Thomson } \\
\text { et al. [95] } \\
\text { Home } \\
\text { visiting } \\
\text { program }\end{array}$ & $\begin{array}{l}\text { Design: Quasi- } \\
\text { experimental. } \\
\text { Data: 2nd } \\
\text { pregnancy } \\
\text { trimester, } 12 \text { mo } \\
\text { p.p. }\end{array}$ & $\begin{array}{l}n=39 \text { intervention, } n=43 \\
\text { control 96.3\% AA, Mississippi }\end{array}$ & $\begin{array}{l}\text { PAT home visiting curriculum }+ \\
\text { culturally tailored pregnancy weight } \\
\text { gain and early childhood obesity } \\
\text { prevention lessons }\end{array}$ & $\begin{array}{l}\text { No effect of intervention on } \\
\text { BF outcomes }\end{array}$ & Very Low \\
\hline $\begin{array}{l}\text { Furman et al. } \\
\text { [96] } \\
\text { Home } \\
\text { visiting } \\
\text { program }\end{array}$ & $\begin{array}{l}\text { Design: Quasi-exp } \\
\text { Data: intake } \\
\text { survey, home visits } \\
\text { and phone calls } \\
\text { logs }\end{array}$ & $\begin{array}{l}n=1000 \text { in interventions } \\
84.3 \% \mathrm{AA} ; n=296 \mathrm{no} \\
\text { intervention; } 80 \% \mathrm{AA} ; \text { Cleveland }\end{array}$ & $\begin{array}{l}\text { Home visiting program and/or Doula } \\
\text { or father's evening program }\end{array}$ & $\begin{array}{l}\text { No effect of interventions } \\
\text { on BF outcomes. More } \\
\text { home-visits increased EBF } \\
\text { and any BF odds. }\end{array}$ & Very low \\
\hline $\begin{array}{l}\text { Lewkowitz } \\
\text { et al. [97] } \\
\text { Home } \\
\text { visiting } \\
\text { program }\end{array}$ & $\begin{array}{l}\text { Design: Quasi- } \\
\text { experimental. } \\
\text { Data: phone } \\
\text { survey; 6-12 mo. } \\
\text { p.p. }\end{array}$ & $\begin{array}{l}\mathrm{n}=59 \text { intervention; } n=59 \\
\text { control; all AA; St. Louis Missouri }\end{array}$ & $\begin{array}{l}\text { Parent educator home visits; } \\
\text { parenting curricula + healthy lifestyle } \\
\& \text { BF education }\end{array}$ & $\begin{array}{l}\text { No effect of intervention on } \\
\text { BF outcomes }\end{array}$ & Low \\
\hline $\begin{array}{l}\text { Leruth et al. } \\
\text { [98] } \\
\text { Office/Home } \\
\text { visiting } \\
\text { program }\end{array}$ & $\begin{array}{l}\text { Design: Pre/post } \\
\text { Data: pre- BF } \\
\text { program data; } \\
\text { baseline and } 6 \text { mo } \\
\text { p.p. post-BF data }\end{array}$ & $\begin{array}{l}n=280 ; \text { mostly AA } \\
\text { Chicago, Illinois }\end{array}$ & $\begin{array}{l}\text { Healthy Start BF model; home/office } \\
\text { based services + BF counseling } \\
\text { pregnancy to } 6 \text { months p.p. delivered } \\
\text { by a CLC }\end{array}$ & $\begin{array}{l}\text { Higher BF initiation and } \\
\text { \%any BF at } 6 \text { mo. after } \\
\text { incorporating BF } \\
\text { component. }\end{array}$ & Very low \\
\hline $\begin{array}{l}\text { Kozhimannil } \\
\text { et al. [99] }\end{array}$ & $\begin{array}{l}\text { D.esign: } \\
\text { Observational } \\
\text { Data: 2009/2010 } \\
\text { PRAMS and } \\
\text { Medicaid, } \\
\text { program's logs }\end{array}$ & $\begin{array}{l}n=1069 \text { intervention } 10.1 \% \text { W; } \\
46.6 \% \mathrm{AA} ; 36.5 \% \mathrm{H} ; 5.5 \% \text { Asian; } \\
\text { 1.0\%Al; } 0.3 \% \text { other. } \\
n=51,721 \text { PRAMS }\end{array}$ & $\begin{array}{l}\text { Pregnant women with Medicaid } \\
\text { coverage vs. pregnant women with } \\
\text { Medicaid coverage + Doula from } \\
\text { non-profit organization }\end{array}$ & $\begin{array}{l}\text { Higher percentage of } \\
\text { women who had doula- } \\
\text { supported births-initiated } \\
\text { BF }\end{array}$ & Low \\
\hline $\begin{array}{l}\text { Rotheram- } \\
\text { Fuller et al. } \\
{[100]} \\
\text { Home } \\
\text { visiting } \\
\text { program }\end{array}$ & $\begin{array}{l}\text { Design: RCT } \\
\text { Data: surveys; } \\
\text { baseline, } 2 \text { wks } \\
\text { p.p., } 6 \text { mo p.p. }\end{array}$ & $\begin{array}{l}\mathrm{n}=99 \text { intervention } \\
n=104 \text { controls; } 80 \% \mathrm{H} ; \mathrm{LA}\end{array}$ & $\begin{array}{l}\text { Home visiting BF Peer Mentor } \\
\text { Mothers (MM) }\end{array}$ & $\begin{array}{l}\text { No effect of intervention on } \\
\text { BF outcomes }\end{array}$ & Very low \\
\hline
\end{tabular}

Abbreviations: AA African American; Al American Indian; AN Alaskan Native; $H$ Hispanic; $W$ White; NS not significant; $p . p$. postpartum; $P C$ peer counselor; $R C T$ Randomized Controlled Trial CHW, Community Health Worker; NFN Nurturing Family Network; FSW Family Support Worker; PAT Parent as Teacher; CLC Certified Lactation Counselor ${ }^{\mathrm{a}}$ National Pediatric Nutrition Surveillance System (PedNSS) data for Al families 
Table 10 Interpersonal level breastfeeding interventions among women of color in the U.S.

\begin{tabular}{|c|c|c|c|c|c|}
\hline $\begin{array}{l}\text { Study/ } \\
\text { Settings }\end{array}$ & Study Design/methods & Study Population & Intervention & Outcomes/Results & Grade \\
\hline $\begin{array}{l}\text { Ashida } \\
\text { et al. } \\
\text { [101] }\end{array}$ & $\begin{array}{l}\text { Design: Cross-sectional } \\
\text { Data: } 20-45 \text { minute survey }\end{array}$ & $\begin{array}{l}\mathrm{n}=81 \text { mothers; } 80 \% \\
\text { AA; } \\
\text { City in the South }\end{array}$ & $\begin{array}{l}\text { Receiving supportive vs. } \\
\text { undermining BF information } \\
\text { from social networks }\end{array}$ & $\begin{array}{l}\text { Participants who received more supportive } \\
\text { than undermining BF advice were more } \\
\text { likely to ever BF }\end{array}$ & $\begin{array}{l}\text { Very } \\
\text { Low }\end{array}$ \\
\hline $\begin{array}{l}\text { Thomas } \\
\text { et al. } \\
\text { [102] }\end{array}$ & $\begin{array}{l}\text { Design: Cross-sectional } \\
\text { Data: two 5-min surveys } \\
\text { for mothers \& accompany- } \\
\text { ing person }\end{array}$ & $\begin{array}{l}\mathrm{n}=192 \text { mothers; } 101 \\
\text { with accompanying } \\
\text { adult }\end{array}$ & $\begin{array}{l}\text { Mothers with vs. mothers } \\
\text { without accompanying person }\end{array}$ & $\begin{array}{l}\text { Mothers with accompanying person more } \\
\text { likely to EBF }\end{array}$ & Low \\
\hline $\begin{array}{l}\text { Wilhelm } \\
\text { et al. } \\
\text { [103] }\end{array}$ & $\begin{array}{l}\text { Design: RCT } \\
\text { Data: } 3 \text { d, } 2,6 \text { wks pp. } \\
\text { surveys and } 6 \text { months } \\
\text { phone interview. }\end{array}$ & $\begin{array}{l}\mathrm{n}=26 \text { intervention; } \\
\mathrm{n}=27 \text { controls; } \mathrm{All} \mathrm{H}\end{array}$ & $\begin{array}{l}\text { BF motivational interviewing } \\
\text { session at } 3 d, 2 \& 3 \text { ws pp. }\end{array}$ & $\begin{array}{l}\text { No between-group differences } 3 \mathrm{BF} \text { at } 6 \\
\text { mo }\end{array}$ & $\begin{array}{l}\text { Very } \\
\text { Low }\end{array}$ \\
\hline
\end{tabular}

Abbreviations: AA African-American; $H$ Hispanic; $R C T$ Randomized Controlled Trial; $p p$. postpartum

greatest benefit among minority women. Policies at the state level that required employers to provide adequate breaks and space benefited Hispanic by strengthening $\mathrm{BF}$ initiation and BF duration to 6 months plus improving ever BF among Black women. Furthermore, Black women were more likely to initiate BF in states where there were laws protecting $\mathrm{BF}$ in public and private locations [43]. However, unexpectedly, in a low quality observational study, Black women were less likely to continue $\mathrm{BF}$ for 6 months compared with White women in states with BF laws providing breaks, exemption for jury duty, and workplace pumping laws [44].

It is clear from these studies that racial/ethnic groups were affected differently by state-level BF supporting laws. This is not surprising because returning to work and low socio-economic status are both risk factors for suboptimal BF outcomes in the general population [105]. Indeed, in 2018, Black women in the U.S. were more likely to be working (62.4\%) compared with White (57.6\%), Asian (58.6\%), or Hispanic (59.4\%) women. Among women with children under 18 years old, Black women $(77.2 \%)$ were also more likely to be working than White (71.2\%), Asian (65.0\%), or Hispanic women (63.9\%) [106] . Even though most BF workplace laws have limitations, including weak enforcing mechanisms, they were positively associated with BF initiation and with decreased inequities in this outcome. However, the effect sizes were small suggesting that maternity protection policies need to be strengthened to further support BF among minority women in the U.S. Since paid maternity leave has been associated with improved BF initiation and duration $[107,108]$, it is indeed important to develop strong, enforceable federal paid maternity leave policies in the U.S. These policies are needed by lowincome women, including those belonging to ethnic/racial minority groups, many of which have jobs incompatible with BF. It is important to pay special attention to structural inequities in the types of employments related to immigration status. For instance, undocumented immigrants may have less access to any kind of maternity protection benefits as a result of informal employment.

Our findings also suggest that laws protecting women's rights to breastfeed in public and private places facilitate BF among minority women. More research is needed to understand how to translate BF supportive policies into programs that are tailored to the needs of women following a socioecological model approach.

Changes to the Supplemental Nutrition Program for Women, Infants and Children (WIC) packages in 2009 designed to incentivize BF represent an important policy "experiment" that is highly relevant to ethnic/racial minority women. WIC is a food assistance federal program serving low-income pregnant and post-partum women, and their children under 5 years old. WIC serves over half of the annual births in the country and has strong representation from ethnic/racial minority groups. WIC program staff are required to provide nutrition education and anticipatory guidance on BF to pregnant women plus post-partum BF support to mothers who choose to breastfeed. WIC also offers food packages designed to supplement the nutritional needs of mothers and infants with healthy foods, and the 2009 package was also designed to incentivize BF. In our review, we found that the 2009 WIC package revisions seem to have a positive impact on BF practices. Specifically, an NHANES analysis found that the changes in the WIC package made WIC participant children to initiate breastfeeding at rates similar to non-WIC participating eligible children, while this was not the case for BF duration at 6 months [45]. Another pre/post study conducted in Los Angeles county among WIC participants, found that 2009 WIC package changes positively influenced BF initiation and the likelihood of EBF at 3 and 6 months [46]. A previous review found mixed results on the relationship between WIC 2009 food package revisions and BF outcomes in the general WIC population, and it is possible that these relationships are different across different states [109]. Hence, more research is 
needed to further elucidate if and how these changes affected BF outcomes across different states and ethnic/racial minority groups.

In summary, with regards to policy level interventions, we found that federal and state laws and policies supporting $\mathrm{BF}$ have indeed been positively associated with BF initiation among minority and low-income women. However, it is necessary to go beyond these policies to improve success with BF duration and EBF across minority and low-socioeconomic groups by considering paid maternity leave and access to high quality BF support at the health facility and community levels. The WIC program could play a key role by implementing additional package changes recommended by the National Academy of Medicine in 2016 to further incentivize BF and building from lessons learned from the 2006 WIC package revisions [110].

\section{Community level}

At the community level of the socioecological model, we identified studies examining interventions or exposures driven by health care facilities, WIC, and community agencies.

\section{Healthcare facilities}

The majority of the BF interventions reviewed in this section of the SR were related to MCP based on the Ten Steps from the Baby Friendly Hospital Initiative (BFHI). Our review shows that these practices influence BF outcomes. The CHAMPS intervention, located in hospitals across 4 Southern states, found that the process of becoming a Baby Friendly Hospital was effective at improving BF outcomes in an ethnic/racially diverse group of women and closed the gap in BF initiation among African American women [53].

Feeding only breastmilk in hospital was strongly associated with longer BF duration among women from multiple ethnicities/races, but studies also documented differential responses as a function of maternal ethnicity/race. Unexpectedly, one study found that receiving $\mathrm{BF}$ information and support at the hospital was negatively associated with BF duration among Black women [54]. Another study found that Hispanic and Native American women were less likely to have given a telephone number to call if they needed BF support after hospital discharge [55] perhaps as a result of stereotyping of BF behaviors [20].

In addition, the provision of formula at the hospital and formula gifts at discharge was associated with suboptimal BF practices among Hispanic women [54]. This finding is consistent with previous studies that have found that Hispanic women tend to have a strong preference for mixed feeding $[69,111]$.
In our SR, we also found evidence that multi-point maternity care interventions that have prenatal, perinatal, and post-partum components including PCs together with International Board Certified Lactation Consultants (IBCLCs) or other health professionals can have a strong impact on EBF and/or any BF duration $[65,66,69,70]$ This agrees with previous literature reviews focusing on the global $\mathrm{BF}$ counseling evidence, including from the U. S. [35, 112, 113]

In summary, on the one hand, our SR indicates that maternity care practices consistent with the Ten Steps improve $\mathrm{BF}$ outcomes among minority women and can contribute to decreasing $\mathrm{BF}$ disparities. On the other hand, it documents the need to include cross-cultural training for maternity care staff to learn how to better tailor their support to the specific needs of Black and Hispanic women to improve BF rates, which is consistent with previous recommendations [35].

\section{WIC}

Participation in the WIC program has been consistently associated with lower BF rates when comparing WIC mothers with WIC-eligible women not enrolled in the program [114]. An analysis of 2004-2008 Mississippi PRAMS found that WIC participation was not associated with BF initiation or duration among Black mothers when compared with their White counterparts [80]. In our review, several RCTs tested the impact of enhancements to BF support services offered by on BF outcomes. An innovative study showed that increasing monthly financial incentives for BF among Puerto Rican women had a sizable and statistically significant positive impact on increasing BF duration but had no impact on EBF [83]. This is consistent with behavioral economics interventions that have focused on other nutrition behaviors including fruit and vegetable intake among low-income populations in the U.S. [115].

This review also included WIC interventions that focused on the use of information technology to support BF. A RCT found that two-way behavior change text messages initiated by PCs serving WIC mothers in Connecticut did not have a significant impact on EBF at 2 weeks post-partum perhaps due to sample size limitations; yet, the EBF rate was much higher in the intervention than in the control group. This intervention did facilitate establishing earlier contact with the mothers after birth, which is considered to be key for BF success as the onset of many of lactation problems happen during the first few days after birth [85]. Indeed, one of the studies that reviewed identified gaps in WIC BF support services found that by the time of post-partum WIC certification many mothers that had initiated BF were already offering mix feeding to their infants or had stopped BF altogether because they did not receive timely BF support. This observational study found that mothers that received peer 
counseling services were more likely to continue to breastfeed at WIC certification when compared with the other WIC BF support services [81].

Findings from a study on WIC conducted in NY state offices suggests that tailoring interventions to women's individual needs is important for improving EBF rates among Hispanic and Black WIC participants. This is consistent with findings showing that women of different race/ethnicities respond differently to similar BF interventions [116].

\section{Community agencies}

Several BF interventions were delivered to diverse racial/ ethnic groups during pregnancy and the post-partum period by community agencies through community health workers as part of their maternal and child home visiting programs. Overall, our findings indicate these programs were positively associated with BF duration among minority women. Because most of these studies were graded as having very low-quality, it is important that better designed studies are carried out to try to confirm these findings.

\section{Interpersonal level}

There was a dearth of intervention studies that examined the impact of BF support for minority women through their social networks. The few identified in our SR suggest that minority women's support networks can influence the type of BF advice given by friends and relatives and, ultimately, BF practices. Although this is consistent with theoretical expectations [117], this is an area that needs to be better studied among minority women using mixedmethod approaches.

Very few studies reviewed reported specific behavioral change strategies with psychosocial components, however, findings seem to suggest that behavior change driven interventions may have positive effects on BF duration among minority women. More studies among minority women are strongly needed in this area as they are key for learning how best to tailor BF interventions to the needs and wants of different ethnic/racial groups.

\section{Research recommendations}

Only $36 \%(n=22)$ of the articles included in this review included women from more than one racial/ethnic group. Furthermore, $40 \% \quad(n=24)$ of the studies focused on Hispanic mothers only, the majority of which only included women of Mexican origin. About 22\% $(n=13)$ of the studies were conducted among Black women and only $1.6 \%(n=1)$ among American Indian/Alaskan Native women. Hence, there is a strong need to increase the number of ethnic/racial groups represented in BF studies in the U.S. and conduct studies that look at a single ethnic/racial group at a time, especially American Indian/Alaskan Native women.
Consistent with the global evidence [118], MCPs were found to impact BF outcomes among minority women in the U.S. There is now a need to conduct implementation science research [119] to understand how best to scale up and sustain the Baby Friendly Initiative in geographical areas serving ethnic/racial minority women [120, 121] . Given the negative impact that cultural barriers can have on infant feeding behaviors and maternal and child health outcomes [20], such studies need to identify the best approaches to implement effective maternity staff trainings that include a culturally sensitive communication skills building component so as to avoid stereotyping BF behaviors in different ethnic/racial groups [20].

It is notable that we did not identify any study focusing on behavior change social marketing campaigns targeting minority women in the U.S. The persistence of this previously documented gap $[120,122]$ needs to be urgently addressed given how important these campaigns, in combination with other strategies, have been for improved breastfeeding outcomes within other countries [122].

The great majority of studies were graded as being very low or low quality. Future research in this area needs to develop more robust studies. It is important that funding agencies such as NIH and CDC allocate more funding for understanding how best to protect, promote, and support $\mathrm{BF}$ among minority women in the US.

Lastly, no single study formally tested the combined impact of interventions to improve BF outcomes among minority women across different levels of the socioecological model from a multisectoral perspective. The U.S. could benefit from the global experience with evidence-informed policy toolboxes that can guide the development of sound BF protection and promotion, and support research agendas, policies, and programs based on complex adaptive systems frameworks such as the Breastfeeding Gear Model (see Table 1) [31, 123, 124] . Specifically, it will be important for a multisectoral committee to assess the strengths and weaknesses of each of the key enabling environments needed to improve BF outcomes among minority women in the United States. These include evidence-based advocacy with a strong equity lens, political will, legislation and resources for maternity benefits, workforce training and implementation of high quality culturally sensitive facilities and community based BF support programs, culturally appropriated social marketing behavior change communication campaigns, implementation research, and decentralized coordination from the national to the local level [31]. Finding from such assessments can then help inform the design of BF policies and implementation and evaluation of large scale interventions for minority women based on sound human rights and health economics frameworks [26-28]. 


\section{Conclusions}

In conclusion, our SR found that policy and community level interventions at the WIC, health facility, and community agency level are likely to improve BF outcomes. Multi-point interventions that include prenatal, perinatal, and postnatal components including peer counseling are very promising. However, combining interventions at different levels of the socioecological model has not been studied in the U.S. Thus, it is strongly recommended that large scale implementation research that addresses the different health and social environments necessary for successful BF [27] be the next BF research frontier to explore ways to strengthen BF protection, promotion and support among minority women in the U.S.

\section{Supplementary Information}

The online version contains supplementary material available at https://doi. org/10.1186/s12939-021-01388-4.

Additional file 1. Online Supplementary Material 1. MESH terms used in Systematic Review.

Additional file 2. Studies' data extraction information.

\section{Abbreviations}

BF: Breastfeeding; SR: Systematic Review; PRESS: Peer Review Electronic Search Strategies; U.S.: United States of America; HP: Healthy People Initiative; HP2020: Healthy People 2020; EBF: Exclusive BF; CDC: The Centers for Disease Control; NIS: National Immunization Survey; ACA: Affordable Care Act; PRAM S: Pregnancy Risk Assessment Monitoring System; AA: African-American; Al/ AN: American Indian/Alaska Natives; WIC: The Special Supplemental Nutrition Program for Women, Infants and Children; NHANES: National Health and Nutrition Examination Survey; $\mathrm{NIH}$ : National Institute of Health; CPM: Centering Pregnancy Model; BFH: Baby Friendly Hospital; BFHI: Baby Friendly Hospital Initiative; SSC: Skin-to-Skin Contact; PC: Peer Counselor; SID: Sudden Infant Death Syndrome; MCP: Maternal Care Practices; StEP: Starting Early Program; HSP: Healthy Start Program; CHAM PS: Communities and Hospitals Advancing Maternity Practices; LATC H: Lactation Advice Through Texting Can Help; PRISMA: Preferred Reporting Items for Systematic Reviews and Meta-analyses; GRADE: Grades of Recommendation, Assessment, Development, and Evaluation; BFGM: Breastfeeding Gear Model; RCT: Randomized Controlled Trial; CHAM PS: Communities and Hospitals Advancing Maternity Practices initiative; NFN: Nurturing Family Network; IBCLC: Certified Lactation Consultant: CLC: Certified Lactation Counselor

\section{Acknowledgements}

We thank the Harvey Cushing/John Hay Whitney Medical Library, at Yale University for their support conducting the searchers for this systematic review.

\section{Authors' contributions}

SSP led and coordinated this project since its inception. SSP, RPE and AHR, conceived the systematic review which was implemented in strong partnership with MA and KN. SSP wrote the first draft of the article, and all co-authors critically reviewed and made major contributions to it. The author(s) read and approved the final manuscript.

\section{Funding}

Funding: Healthy Eating Research, a national program of the Robert Wood Johnson Foundation based at Duke University. The funder did not have a role in the systematic review design, data collection, analyses, interpretation of results or writing of the manuscript. This project was also supported by the Cooperative Agreement Number 5 U48DP006380-02-00 funded by the Centers for Disease Control and Prevention, Prevention Research Center Program through a grant to the Yale School of Public Health (PI. Rafael Pérez-
Escamilla). Its contents are solely the responsibility of the authors and do not necessarily represent the official views of the Centers for Disease Control and prevention or the Department of Health and Human Services.

\section{Availability of data and materials}

All data generated or analyzed during this study are included in this article and supplementary files.

\section{Ethics approval and consent to participate}

Not applicable.

\section{Consent for publication \\ Not applicable.}

\section{Competing interests}

The authors declare that they have no competing interests.

\section{Author details}

${ }^{1}$ Hispanic Health Council, 175 Main Street, Hartford, CT 06106, USA. ${ }^{2}$ Yale School of Public Health, 135 College Street, New Haven, CT 06510, USA. ${ }^{3}$ Harvey Cushing/John Hay Whitney Medical Library, Yale School of Public Health, New Haven, USA.

Received: 30 October 2020 Accepted: 18 January 2021

Published online: 06 March 2021

References

1. Black RE, Victora CG, Walker SP, Bhutta ZA, Christian P, de Onis M, et al. Maternal and child undernutrition and overweight in low-income and middle-income countries. Lancet. 2013;382(9890):427-51.

2. Binns $C$, Lee M, Low WY. The long-term public health benefits of breastfeeding. Asia Pac J Public Health. 2016;28(1):7-14.

3. Victora CG, Bahl R, Barros AJ, França GV, Horton S, Krasevec J, et al. Breastfeeding in the 21st century: epidemiology, mechanisms, and lifelong effect. Lancet. 2016:387(10017):475-90.

4. Victora CGHB, de Mola CL, et al. Association between breastfeeding and intelligence, educational attainment, and income at 30 years of age: a prospective birth cohort study from Brazil. Lancet Glob Health. 2015;3(4): e199-205.

5. Yan J, Liu L, Zhu Y, Huang G, Wang PP. The association between breastfeeding and childhood obesity: a meta-analysis. BMC Public Health. 2014:14:1267.

6. Qiao J, Dai $\sqcup$, Zhang Q, Ouyang YQ. A meta-analysis of the association between breastfeeding and early childhood obesity. J Pediatr Nurs. 2020;53: 57-66.

7. Ip S, Chung M, Raman G, Trikalinos TA, Lau J. A summary of the Agency for Healthcare Research and Quality's evidence report on breastfeeding in developed countries. Breastfeed Med. 2009:4(Suppl 1):S17-30.

8. Office of Disease Prevention and Health Promotion 2020 HP. Healthy People 2020. [cited 2020 February, 2 ]. Available from: https://www. healthypeople.gov/2020/topics-objectives

9. Office of Disease Prevention and Health Promotion, $2020 \mathrm{HP}$. Healthy People 2020 [cited 2020 2/2/2020]. Available from: https://www. healthypeople.gov/.

10. Center for Disease Control and Prevention. Breastfeeding Report Card: 2020 Division of nutrition, Physical Activity, and Obesity,

11. Centers for Disease Control and Prevention. Breastfeeding Report Card: 2018. United States: National Center for Chronic Disease Prevention and Health Promotion, Division of Nutrition, Physical Activity, and Obesity, 2018.

12. Center for Disease Control and Prevention. Breastfeeding Report-CardUnited States, 2011, 2011 [9/22/2020]. Available from: dc.gov/breastfeeding/ pdf/2011 breastfeedingreportcard.pdf

13. Center for Disease Control and Prevention. Breastfeeding Data. Available from: https://www.cdc.gov/breastfeeding/data/nis_data/rates-any-exclusivebf-socio-dem-2017.html. Accessed 20 Sept 2020.

14. Beauregard JL, Hamner HC, Chen J, Avila-Rodriguez W, Elam-Evans LD, Perrine CG. Racial disparities in breastfeeding initiation and duration among U.S. infants born in 2015. MMWR Morb Mortal Wkly Rep. 2019:68(34):745-8.

15. Anstey EH, Chen J, Elam-Evans LD, Perrine CG. Racial and geographic differences in breastfeeding - United States, 2011-2015. MMWR Morb Mortal Wkly Rep. 2017;66(27):723-7. 
16. Li R, Perrine CG, Anstey EH, Chen J, CA MG, Elam-Evans LD. Breastfeeding Trends by Race/Ethnicity Among US Children Born From 2009 to 2015. JAMA Pediatr. 2019;173:e193319.

17. Louis-Jacques A, Deubel TF, Taylor M, Stuebe AM. Racial and ethnic disparities in U.S. breastfeeding and implications for maternal and child health outcomes. Semin Perinatol. 2017:41(5):299-307.

18. Jones KM, Power ML, Queenan JT, Schulkin J. Racial and ethnic disparities in breastfeeding. Breastfeed Med. 2015;10(4):186-96.

19. Gallo S, Kogan K, Kitsantas P. Racial and ethnic differences in reasons for breastfeeding cessation among women participating in the special supplemental nutrition program for women, infants, and children. J Midwife Women Health. 2019;64(6):725-33.

20. Pérez-Escamilla R, Sellen D. Equity in breastfeeding: where do we go from here? J Hum Lact. 2015;31(1):12-4.

21. Chapman DJ, Pérez-Escamilla R. Acculturative type is associated with breastfeeding duration among low-income Latinas. Matern Child Nutr. 2013; 9(2):188-98.

22. Chantry CJ, Dewey KG, Peerson JM, Wagner EA, Nommsen-Rivers LA. Inhospital formula use increases early breastfeeding cessation among first-time mothers intending to exclusively breastfeed. J Pediatr. 2014;164(6):1339-45 e5.

23. Brown A. Among women planning to exclusively breastfeed, in-hospital formula supplementation is associated with almost tripled risk of breastfeeding cessation by 2 months. Evid Based Nurs. 2015;18(3):68.

24. Li R, Perrine CG, Anstey EH, Chen J, MacGowan CA, Elam-Evans LD, et al. Early Formula Supplementation Trends by Race/Ethnicity Among US Children Born From 2009 to 2015. JAMA Pediatr. 2020;175(2):202-4.

25. Li R, Perrine CG, Anstey EH, Chen J, MacGowan CA, Elam-Evans LD. Breastfeeding Trends by Race/Ethnicity Among US Children Born From 2009 to 2015. JAMA Pediatr. 2019;173(12):e193319.

26. Grummer-Strawn LM, Zehner E, Stahlhofer M, Lutter C, Clark D, Sterken E, et al. New World Health Organization guidance helps protect breastfeeding as a human right. Matern Child Nutr. 2017;13(4):e12491. https://doi.org/10. 1111/mcn.12491.

27. Pérez-Escamilla R. Breastfeeding in the 21st century: how we can make it work. Soc Sci Med. 2020;244:112331.

28. Bartick MC, Jegier BJ, Green BD, Schwarz EB, Reinhold AG, Stuebe AM. Disparities in breastfeeding: impact on maternal and child health outcomes and costs. J Pediatr. 2017;181:49-55 e6.

29. Glanz K, Bishop DB. The role of behavioral science theory in development and implementation of public health interventions. Annu Rev Public Health. 2010;31:399-418.

30. Center for Disease Control and Prevention. The Socio-Ecological Model: Framework for Prevention 2020 [cited 2020 December, 20]. Available from: https://www.cdc.gov/violenceprevention/publichealthissue/socialecologicalmodel.html.

31. Pérez-Escamilla R, Curry L, Minhas D, Taylor L, Bradley E. Scaling up of breastfeeding promotion programs in low- and middle-income countries: the "breastfeeding gear" model. Adv Nutr. 2012;3(6):790-800.

32. Johnson A, Kirk R, Rosenblum KL, Muzik M. Enhancing breastfeeding rates among African American women: a systematic review of current psychosocial interventions. Breastfeed Med. 2015;10(1):45-62.

33. Wouk K, Lara-Cinisomo S, Stuebe AM, Poole C, Petrick JL, McKenney KM. Clinical Interventions to Promote Breastfeeding by Latinas: A Meta-analysis. Pediatrics. 2016;137(1):e20152423. https://doi.org/10.1542/peds.2015-2423.

34. Adams IKR, Okoli CTC, Dulin Keita A, Linares AM, Tanaka K, Polanin JR, et al. Breastfeeding practices among native Hawaiians and Pacific islanders. J Obes. 2016;2016:2489021.

35. Chapman DJ, Pérez-Escamilla R. Breastfeeding among minority women: moving from risk factors to interventions. Adv Nutr. 2012;3(1):95-104.

36. Institute of Medicine. In: Eden J, Levit L, Berg A, Morton S, editors. Finding What Works in Health Care: Standards for Systematic Reviews. Washington: The National Academies Press; 2011. p. 340.

37. Shamseer L, Moher D, Clarke M, Ghersi D, Liberati A, Petticrew M, et al. Preferred reporting items for systematic review and meta-analysis protocols (PRISMA-P) 2015: elaboration and explanation. BMJ. 2015;350:g7647.

38. McGowan J, Sampson M, Salzwedel DM, Cogo E, Foerster V, Lefebvre C. PRESS peer review of electronic search strategies: 2015 guideline statement. J Clin Epidemiol. 2016;75:40-6.

39. Prady SL, Uphoff EP, Power M, Golder S. Development and validation of a search filter to identify equity-focused studies: reducing the number needed to screen. BMC Med Res Methodol. 2018;18(1):106.
40. Veritas Health Innovation. Covidence Systematic review software, Melbourne, Australia [9/22/2020]. Available from: www.covidence.org. Accessed 22 Sept 2020.

41. Guyatt G, Oxman AD, Akl EA, Kunz R, Vist G, Brozek J, et al. GRADE guidelines: 1. Introduction-GRADE evidence profiles and summary of findings tables. J Clin Epidemiol. 2011;64(4):383-94.

42. Kapinos KA, Bullinger L, Gurley-Calvez T. Lactation support services and breastfeeding initiation: evidence from the affordable care act. Health Serv Res. 2017;52(6):2175-96.

43. Hawkins SS, Stern AD, Gillman MW. Do state breastfeeding laws in the USA promote breast feeding? J Epidemiol Community Health. 2013;67(3):250-6.

44. Smith-Gagen J, Hollen R, Walker M, Cook DM, Yang W. Breastfeeding laws and breastfeeding practices by race and ethnicity. Womens Health Issues. 2014;24(1):e11-9.

45. Li K, Wen M, Reynolds M, Zhang Q. WIC Participation and Breastfeeding after the 2009 WIC revision: a propensity score approach. Int J Environ Res Public Health. 2019, 16(15):2645. https://doi.org/10.3390/ijerph16152645.

46. Langellier BA, Chaparro MP, Wang MC, Koleilat M, Whaley SE. The new food package and breastfeeding outcomes among women, infants, and children participants in Los Angeles County. Am J Public Health. 2014;104 Suppl 1(Suppl 1):S112-8.

47. Yourkavitch J, Kane JB, Miles G. Neighborhood disadvantage and neighborhood affluence: associations with breastfeeding practices in urban areas. Matern Child Health J. 2018;22(4):546-55.

48. Chae SY, Chae MH, Kandula S, Winter RO. Promoting improved social support and quality of life with the CenteringPregnancy $\left({ }^{\odot}\right)$ group model of prenatal care. Arch Womens Ment Health. 2017;20(1):209-20.

49. Robertson B, Aycock DM, Darnell LA. Comparison of centering pregnancy to traditional care in Hispanic mothers. Matern Child Health J. 2009;13(3):407-14.

50. Trudnak TE, Arboleda E, Kirby RS, Perrin K. Outcomes of Latina women in CenteringPregnancy group prenatal care compared with individual prenatal care. J Midwifery Womens Health. 2013;58(4):396-403.

51. Farr RS, Rahman F, O'Riordan MA, Furman L. Assessing the feasibility and effectiveness of two prenatal breastfeeding intervention apps in promoting postpartum in-hospital exclusive breastfeeding. Breastfeed Med. 2019;14(10):724-30.

52. Louis-Jacques AF, Wilson R, Dean K, Hernandez I, Spatz D, Običan S. Improving drug exposure knowledge during lactation: quality improvement initiative in Low-income women. Breastfeed Med. 2020;15(3):140-6.

53. Merewood A, Bugg K, Burnham L, Krane K, Nickel N, Broom S, et al. Addressing Racial Inequities in Breastfeeding in the Southern United States. Pediatrics. 2019;143(2):e20181897. https://doi.org/10.1542/peds.2018-1897.

54. Ahluwalia IB, Morrow B, D'Angelo D, Li R. Maternity care practices and breastfeeding experiences of women in different racial and ethnic groups: pregnancy risk assessment and monitoring system (PRAMS). Matern Child Health J. 2012;16(8):1672-8.

55. Sebastian RA, Coronado E, Otero MD, McKinney CR, Ramos MM. Associations between maternity care practices and 2-month breastfeeding duration vary by race, ethnicity, and acculturation. Matern Child Health J. 2019;23(6):858-67.

56. Nobari TZ, Jiang L, Wang MC, Whaley SE. Baby-friendly hospital initiative and breastfeeding among WIC-participating infants in Los Angeles County. J Hum Lact. 2017;33(4):677-83.

57. Jung S, Nobari TZ, Whaley SE. Breastfeeding outcomes among WICparticipating infants and their relationships to baby-friendly hospital practices. Breastfeed Med. 2019;14(6):424-31.

58. Linares AM, Wambach K, Rayens MK, Wiggins A, Coleman E, Dignan MB. Modeling the influence of early skin-to-skin contact on exclusive breastfeeding in a sample of Hispanic immigrant women. J Immigr Minor Health. 2017;19(5):1027-34.

59. Ekambaram $\mathrm{M}$, Irigoyen MM, Paoletti A, Siddiqui I I Impact of a baby-friendly-aligned pacifier policy on pacifier use at 1 month of age. Acad Pediatr. 2019;19(7):808-14.

60. Messito MJ, Katzow MW, Mendelsohn AL, Gross RS. Starting early program impacts on feeding at infant 10 months age: a randomized controlled trial. Child Obes. 2020;16(S1):S4-S13.

61. Kao JC, Johnson JE, Todorova R, Zlotnick C. The positive effect of a group intervention to reduce postpartum depression on breastfeeding outcomes in Low-income women. Int J Group Psychother. 2015;65(3):445-58.

62. Watt TT, Appel L, Lopez V, Flores B, Lawhon B. A primary care-based early childhood nutrition intervention: evaluation of a pilot program serving Lowincome Hispanic women. J Racial Ethn Health Disparities. 2015;2(4):537-47.

63. Schreck PK, Solem K, Wright T, Schulte C, Ronnisch KJ, Szpunar S. Both prenatal and postnatal interventions are needed to improve breastfeeding outcomes in a Low-income population. Breastfeed Med. 2017;12:142-8. 
64. Efrat MW, Esparza S, Mendelson SG, Lane CJ. The effect of lactation educators implementing a telephone-based intervention among lowincome Hispanics: a randomised trial. Health Educ J. 2015;74(4):424-41.

65. Wambach KA, Aaronson L, Breedlove G, Domian EW, Rojjanasrirat W, Yeh HW. A randomized controlled trial of breastfeeding support and education for adolescent mothers. West J Nurs Res. 2011;33(4):486-505.

66. Edwards RC, Thullen MJ, Korfmacher J, Lantos JD, Henson LG, Hans SL. Breastfeeding and complementary food: randomized trial of community doula home visiting. Pediatrics. 2013;132(Suppl 2):S160-6.

67. Petrova A, Ayers C, Stechna S, Gerling JA, Mehta R. Effectiveness of exclusive breastfeeding promotion in low-income mothers: a randomized controlled study. Breastfeed Med. 2009;4(2):63-9.

68. Gross RS, Mendelsohn AL, Gross MB, Scheinmann R, Messito MJ. Randomized controlled trial of a primary care-based child obesity prevention intervention on infant feeding practices. J Pediatr. 2016;174:171-7 e2.

69. Linares AM, Cartagena D, Rayens MK. Las dos Cosas versus exclusive breastfeeding: a culturally and linguistically exploratory intervention study in Hispanic mothers living in Kentucky. J Pediatr Health Care. 2019;33(6):e46-56.

70. Chapman DJ, Morel K, Bermúdez-Millán A, Young S, Damio G, PérezEscamilla R. Breastfeeding education and support trial for overweight and obese women: a randomized trial. Pediatrics. 2013;131(1):e162-70.

71. Pugh LC, Serwint JR, Frick KD, Nanda JP, Sharps PW, Spatz DL, et al. A randomized controlled community-based trial to improve breastfeeding rates among urban low-income mothers. Acad Pediatr. 2010;10(1):14-20.

72. Moon RY, Mathews A, Joyner BL, Oden RP, He J, McCarter R Jr. Impact of a randomized controlled trial to reduce Bedsharing on breastfeeding rates and duration for African-American infants. J Community Health. 2017;42(4):707-15.

73. Hopkinson J, Konefal GM. Assignment to a hospital-based breastfeeding clinic and exclusive breastfeeding among immigrant Hispanic mothers: a randomized, controlled trial. J Hum Lact. 2009;25(3):287-96.

74. Bunik M, Shobe P, O'Connor ME, Beaty B, Langendoerfer S, Crane L, et al. Are 2 weeks of daily breastfeeding support insufficient to overcome the influences of formula? Acad Pediatr. 2010;10(1):21-8.

75. Harris-Luna ML, Badr LK. Pragmatic trial to evaluate the effect of a Promotora telephone intervention on the duration of breastfeeding. J Obstet Gynecol Neonatal Nurs. 2018;47(6):738-48.

76. Howell EA, Bodnar-Deren S, Balbierz A, Parides M, Bickell N. An intervention to extend breastfeeding among black and Latina mothers after delivery. Am J Obstet Gynecol. 2014;210(3):239 e1-5.

77. Bream $E, L i H$, Furman $L$. The effect of breast pump use on exclusive breastfeeding at 2 months postpartum in an Inner-City population. Breastfeed Med. 2017;12:149-55.

78. Mercier RJ, Burcher TA, Horowitz R, Wolf A. Differences in breastfeeding among Medicaid and commercially insured patients: a retrospective cohort study. Breastfeed Med. 2018;13(4):286-91.

79. Martinez-Brockman JL, Shebl FM, Harari N, Pérez-Escamilla R. An assessment of the social cognitive predictors of exclusive breastfeeding behavior using the health action process approach. Soc Sci Med. 2017;182:106-16.

80. Marshall C, Gavin L, Bish C, Winter A, Williams L, Wesley M, et al. WIC participation and breastfeeding among white and Black mothers: data from Mississippi. Matern Child Health J. 2013;17(10):1784-92.

81. Gross SM, Resnik AK, Nanda JP, Cross-Barnet C, Augustyn M, Kelly L, et al. Early postpartum: a critical period in setting the path for breastfeeding success. Breastfeed Med. 2011;6(6):407-12.

82. Committee to Review WIC Food Packages; Food and Nutrition Board; Institute of Medicine. National Academies of Sciences $E$, and Medicine. In: Rasmussen KM, Latulippe ME, Yaktine AL, editors. Review of WIC Food Packages: Proposed Framework for Revisions: Interim Report. Washington DC: 2016 by the National Academy of Sciences; 2016.

83. Washio Y, Humphreys M, Colchado E, Sierra-Ortiz M, Zhang Z, Collins BN, et al. Incentive-based Intervention to Maintain Breastfeeding Among Lowincome Puerto Rican Mothers. Pediatrics. 2017;139(3):e20163119. https:// doi.org/10.1542/peds.2016-3119.

84. Harari N, Rosenthal MS, Bozzi V, Goeschel L, Jayewickreme T, Onyebeke C, et al. Feasibility and acceptability of a text message intervention used as an adjunct tool by WIC breastfeeding peer counsellors: The LATCH pilot. Matern Child Nutr. 2018;14(1):e12488. https://doi.org/10.1111/mcn.12488.

85. Martinez-Brockman JL, Harari N, Segura-Pérez S, Goeschel L, Bozzi V, PérezEscamilla R. Impact of the lactation advice through texting can help (LATC $\mathrm{H})$ trial on time to first contact and exclusive breastfeeding among WIC participants. J Nutr Educ Behav. 2018;50(1):33-42 e1.
86. Lovera D, Sanderson M, Bogle ML, Vela Acosta MS. Evaluation of a breastfeeding peer support program for fathers of Hispanic participants in a Texas special supplemental nutrition program for women, infants, and children. J Am Diet Assoc. 2010;110(11):1696-702.

87. Reeder JA, Joyce T, Sibley K, Arnold D, Altindag O. Telephone peer counseling of breastfeeding among WIC participants: a randomized controlled trial. Pediatrics. 2014;134(3):e700-9.

88. Edmunds LS, Lee FF, Eldridge JD, Sekhobo JP. Outcome evaluation of the you can do it initiative to promote exclusive breastfeeding among women enrolled in the New York state WIC program by race/ethnicity. J Nutr Educ Behav. 2017;49(7 Suppl 2):S162-S8 e1.

89. Scheinmann R, Chiasson MA, Hartel D, Rosenberg TJ. Evaluating a bilingual video to improve infant feeding knowledge and behavior among immigrant Latina mothers. J Community Health. 2010;35(5):464-70.

90. Cloutier MM, Wiley JF, Kuo CL, Cornelius T, Wang Z, Gorin AA. Outcomes of an early childhood obesity prevention program in a low-income community: a pilot, randomized trial. Pediatr Obes. 2018;13(11):677-85.

91. Sandy JM, Anisfeld E, Ramirez E. Effects of a prenatal intervention on breastfeeding initiation rates in a Latina immigrant sample. J Hum Lactation. 2009;25(4):404-11 quiz 58-9.

92. Lutenbacher M, Elkins T, Dietrich MS, Riggs A. The efficacy of using peer mentors to improve maternal and infant health outcomes in Hispanic families: findings from a randomized clinical trial. Matern Child Health J. 2018;22(Suppl 1):92-104

93. Hans SL, Edwards RC, Zhang Y. Randomized controlled trial of doula-homevisiting services: impact on maternal and infant health. Matern Child Health J. 2018;22(Suppl 1):105-13.

94. Karanja N, Lutz T, Ritenbaugh C, Maupome G, Jones J, Becker T, et al. The TOTS community intervention to prevent overweight in American Indian toddlers beginning at birth: a feasibility and efficacy study. J Community Health. 2010;35(6):667-75.

95. Thomson JL, Tussing-Humphreys LM, Goodman MH, Landry AS, Olender SE. Low rate of initiation and short duration of breastfeeding in a maternal and infant home visiting project targeting rural, southern, African American women. Int Breastfeed J. 2016;12:15.

96. Furman L, Matthews L, Davis V, Killpack S, O'Riordan MA. Breast for success: a community-academic collaboration to increase breastfeeding among high-risk mothers in Cleveland. Prog Community Health Partnersh. 2016;10(3):341-53.

97. Lewkowitz AK, López JD, Stein RI, Rhoades JS, Schulz RC, Woolfolk CL, et al. Effect of a home-based lifestyle intervention on breastfeeding initiation among socioeconomically disadvantaged African American women with overweight or obesity. Breastfeed Med. 2018;13(6):418-25.

98. Leruth C, Goodman J, Bragg B, Gray D. A multilevel approach to breastfeeding promotion: using healthy start to deliver individual support and drive collective impact. Matern Child Health J. 2017;21(Suppl 1):4-10.

99. Kozhimannil KB, Attanasio LB, Hardeman RR, O'Brien M. Doula care supports near-universal breastfeeding initiation among diverse, low-income women. J Midwifery Womens Health. 2013;58(4):378-82.

100. Rotheram-Fuller EJ, Swendeman D, Becker KD, Daleiden E, Chorpita B, Harris $\mathrm{DM}$, et al. Replicating evidence-based practices with flexibility for perinatal home visiting by paraprofessionals. Matern Child Health J. 2017;21(12):2209-18.

101. Ashida S, Lynn FB, Williams NA, Schafer EJ. Competing infant feeding information in mothers' networks: advice that supports $\mathrm{v}$. undermines clinical recommendations. Public Health Nutr. 2016;19(7):1200-10.

102. Thomas C, O'Riordan MA, Furman L. Effect of the knowledge and attitudes of a support person on maternal feeding choice. J Hum Lact. 2017;33(1): 195-204.

103. Wilhelm SL, Aguirre TM, Koehler AE, Rodehorst TK. Evaluating motivational interviewing to promote breastfeeding by rural Mexican-American mothers: the challenge of attrition. Issues Compr Pediatr Nurs. 2015;38(1):7-21.

104. Hamner HC, Beauregard JL, Li R, Nelson JM, Perrine CG. Meeting breastfeeding intentions differ by race/ethnicity, Infant and Toddler Feeding Practices Study-2. Matern Child Nutr. 2020:e13093. Epub ahead of print 2020 Oct. 1.

105. Sayres S, Visentin L. Breastfeeding: uncovering barriers and offering solutions. Curr Opin Pediatr. 2018;30(4):591-6.

106. U.S. BUREAU OF LABOR STATISTICS. Labor force characteristics by race and ethnicity, 20182019 [cited 2020 October, 17]. Available from: https://www. bls.gov/opub/reports/race-and-ethnicity/2018/home.htm\#: :text=The\%2 Demployment\%E2\%80\%93population\%20ratio\%20was,\%2C\%205\%2C\%2 0and\%205A.). 
107. Vilar-Compte M, Teruel GM, Flores-Peregrina D, Carroll GJ, Buccini GS, PerezEscamilla R. Costs of maternity leave to support breastfeeding; Brazil, Ghana and Mexico. Bull World Health Organ. 2020;98(6):382-93.

108. Andres E, Baird S, Bingenheimer JB, Markus AR. Maternity leave access and health: a systematic narrative review and conceptual framework development. Matern Child Health J. 2016;20(6):1178-92.

109. Schultz DJ, Byker Shanks C, Houghtaling B. The impact of the 2009 special supplemental nutrition program for women, infants, and children food package revisions on participants: a systematic review. J Acad Nutr Diet. 2015;115(11):1832-46.

110. National Academy of Sciences. In: Rasmussen KM, Latulippe ME, Yaktine AL, editors. Review of WIC Food Packages: An Evaluation of White Potatoes in the Cash Value Voucher: Letter Report. Washington DC: 2015 by the National Academy of Sciences; 2015.

111. Bartick M, Reyes C. Las dos cosas: an analysis of attitudes of Latina women on non-exclusive breastfeeding. Breastfeed Med. 2012;7(1):19-24.

112. Rollins NC, Bhandari N, Hajeebhoy N, Horton S, Lutter CK, Martines JC, et al. Why invest, and what it will take to improve breastfeeding practices? Lancet. 2016;387(10017):491-504.

113. Chapman DJ, Morel K, Anderson AK, Damio G, Pérez-Escamilla R. Breastfeeding peer counseling: from efficacy through scale-up. J Hum Lact. 2010;26(3):314-26.

114. Joyce T, Reeder J. Changes in breastfeeding among WIC participants following implementation of the new food package. Matern Child Health J. 2015;19(4):868-76.

115. Snelling AM, Yamamoto JJ, Belazis LB, Seltzer GR, McClave RL, Watts E. Incentivizing supplemental nutrition assistance program purchases with fresh produce in corner stores to reduce food inequity in underserved areas of Washington DC. Health Equity. 2020;4(1):386-93.

116. Anderson AK, Damio G, Chapman DJ, Pérez-Escamilla R. Differential response to an exclusive breastfeeding peer counseling intervention: the role of ethnicity. J Hum Lact. 2007;23(1):16-23.

117. Carlin RF, Mathews A, Oden R, Moon RY. The influence of social networks and norms on breastfeeding in African American and Caucasian mothers: a qualitative study. Breastfeed Med. 2019;14(9):640-7.

118. Pérez-Escamilla R, Martinez IL, Segura-Pérez S. Impact of the baby-friendly hospital initiative on breastfeeding and child health outcomes: a systematic review. Matern Child Nutr. 2016;12(3):402-17.

119. Tumilowicz A, Ruel MT, Pelto G, Pelletier D, Monterrosa EC, Lapping K, et al. Implementation Science in Nutrition: Concepts and Frameworks for an Emerging Field of Science and Practice. Curr Dev Nutr. 2019;3(3):nzy080.

120. Pérez-Escamilla R. Breastfeeding social marketing: lessons learned from USDA's "loving support" campaign. Breastfeed Med. 2012;7(5):358-63.

121. Pérez-Escamilla RV-CM, Rhodes EC, Sarmiento OL, Corvalan C, Sturke R. Susan Vorkoper ,. Implementation of Childhood Obesity Prevention and Control Policies in the US and Latin America: Lessons for Cross-Borders Research and Practice. Obes Rev (under review). 2020.

122. Menon P, Nguyen PH, Saha KK, Khaled A, Kennedy A, Tran LM, et al. Impacts on breastfeeding practices of at-scale strategies that combine intensive interpersonal counseling, mass media, and community mobilization: results of cluster-randomized program evaluations in Bangladesh and Viet Nam. PLoS Med. 2016;13(10):e1002159.

123. Pérez-Escamilla R, Hromi-Fiedler AJ, Gubert MB, Doucet K, Meyers S, Dos Santos Buccini G. Becoming breastfeeding friendly index: development and application for scaling-up breastfeeding programmes globally. Matern Child Nutr. 2018;14(3):e12596.

124. Hromi-Fiedler AJ, Dos Santos BG, Gubert MB, Doucet K, Pérez-Escamilla R. Development and pretesting of "becoming breastfeeding friendly": empowering governments for global scaling up of breastfeeding programmes. Matern Child Nutr. 2019;15(1):e12659.

\section{Publisher's Note}

Springer Nature remains neutral with regard to jurisdictional claims in published maps and institutional affiliations.

Ready to submit your research? Choose BMC and benefit from:

- fast, convenient online submission

- thorough peer review by experienced researchers in your field

- rapid publication on acceptance

- support for research data, including large and complex data types

- gold Open Access which fosters wider collaboration and increased citations

- maximum visibility for your research: over $100 \mathrm{M}$ website views per year

At $\mathrm{BMC}$, research is always in progress.

Learn more biomedcentral.com/submissions 